\title{
En la pampa los diablos andan sueltos. Demonios danzantes de la fiesta del santuario de La Tirana
}

\section{In the Pampa the Devils are roaming loose. Dancing Devils in the Feast of the Shrine of La Tirana}

\author{
por \\ Alberto Díaz Araya ${ }^{2}$ \\ Universidad de Tarapacá, Departamento de Ciencias Históricas \\ y Geográficas, Chile \\ albertodiaz@uta.cl
}

Este artículo analiza a los danzantes que para la fiesta de La Tirana visten trajes de demonios. Se denominan localmente como diablos sueltos. Tanto los componentes etnohistóricos y el universo simbólico de sus atributos como bailarines son estudiados. Para este efecto se releva información social, cultural y musical de los diablos y se destaca que la autonomía de los bailarines es su principal condición, al no pertenecer a ninguna cofradía religiosa que asiste a este significativo santuario del Norte de Chile.

Palabras clave: diablos sueltos, danzas, La Tirana, Norte de Chile.

The article deals with those dancers clad as devils in the feast of La Tirana who are known locally as loose devils. Both the ethnohistoric components and the symbolic universe of their attributes as dancers are studied. Social, cultural and musical data about the devils are presented. The autonomy of the dancers is outlined as their main feature as they do not belong to any of the religious groups attending the feast at this important shrine in Northern Chile.

Key words: loose devils, dances, La Tirana, Northern Chile.

${ }^{1}$ Artículo resultado de los proyectos FONDECYT N 1100132 y del Proyecto de Investigación Mayor de Ciencia y Tecnología de la Universidad de Tarapacá, N 5730 - 10. Asimismo, se agradece el apoyo del Convenio de Desempeño Universidad de Tarapacá-Mineduc.

${ }^{2}$ Mediante este formato, extiendo un homenaje a mis antepasados bailarines de "diablos sueltos" y "osos", Jimmy Díaz Salinas (apodado el "Loco"), Luis Díaz Salinas (conocido como el "Yaco Monty iquiqueño"), así también a "Cafiolo", el "Chino", el "Tabilo" y Ricardo González Cruz, popularmente llamado "el Indio", quienes ya partieron junto a otros más, a danzar en las llanuras del tiempo eterno. Agradezco asimismo, el apoyo de César Alarcón Fernández (“cucaco"), Juan Ríos Castillo, Luis Vivar Carmona, amigos de mil jornadas iquiqueñas y tiraneñas tras danzar de diablo. 


\section{INTRODUCGIÓN}

Las imágenes que circulan en los medios de comunicación masiva o en la propaganda turística sobre la festividad de la Virgen del Carmen de La Tirana en el norte de Chile, ilustran estampas o trípticos de multicolores trajes que visten y engalanan a bailarines, sus coreografías e instrumentaciones musicales, además de las expresiones de sacrificios de los devotos para "pagar" alguna "manda" cumplida por la "Chinita". Asimismo, el zoom periodístico concentra el focus en las representaciones de las “diabladas", las que con enormes máscaras, capas bordadas y elevados saltos, llaman la atención de peregrinos, viajeros y comerciantes durante la medianía del mes de julio ${ }^{4}$. Con el correr de los años, el baile de las "diabladas" se ha convertido en el arquetipo que remite al ejercicio "mnemotécnico" para recordar, describir o imaginar la festividad popular del santuario, incluso con ciertos atisbos folclóricos o paisajísticos.

Este panorama nos permite advertir, mucho más allá del slogan, de las postales o de los souvenirs, cuál es la profundidad temporal de las danzas de diablos y en qué contextos surgen, se adaptan y/o cristalizan esta diversidad de la cultura religiosa popular en los Andes. Estas danzas siguen al unísono los rasgos simbólicos que poseen estas complejas manifestaciones de fe y tradición sociocultural en toda el área de la región tarapaqueña ${ }^{5}$.

A fines de la década de 1980, Lautaro Núñez explicitó, en su esfuerzo por problematizar el misterio del sacramento que contenía el culto Mariano en la Pampa del Tamarugal, que el fenómeno de La Tirana era evidentemente dificultoso de testear en cuanto a una aproximación epistemológica en torno a la empiria, la razón o la fe presentes en él. Sin el ánimo de generar respuestas absolutas, si no invitando a una reflexión sustentada en las ciencias humanas (histórico-hermenéuticas como las denomina Habermas), Lautaro Núñez sugiere una explicación -matizada con la tonalidad del ensayo- que apuesta por una perspectiva antropológica en el análisis de los contextos históricos y sociales implicados en las actividades cúlticas de ritos y mudanzas en el Santuario ${ }^{6}$.

${ }^{3}$ La expresión "Chinita" o "China", corresponde a la denominación que los feligreses utilizan para referirse a la Virgen del Carmen en la festividad. La expresión "pagar" una manda, da cuenta del cumplimiento que deben realizar los devotos por el favor concedido de la Virgen, lo que en la mayoría de los casos se demuestra con la experimentación del sacrificio en el cuerpo del peregrino. Algunos de los bailes que participan en la festividad son los tradicionales "chunchos", los indios siux [sioux], dakotas, pieles rojas, cuyacas, morenos, antawaras, zambos caporales, llameros, tobas, osadas, huasos, marineros, chinos, diabladas, entre muchos otros.

${ }^{4}$ Hasta fines del siglo XIX la festividad era celebraba el 6 de agosto, fecha emblemática en los Andes porque aparte de conmemorar la independencia de Bolivia, se rinde un homenaje al patrono de Sabaya, San Salvador; el 5 de agosto se festeja también a la Virgen de Copacabana en el altiplano boliviano. Debido a las políticas chilenizadoras, la fecha de la fiesta de La Tirana se trasladó al 16 de julio, día de la patrona del ejército chileno. Cf. González 2006.

${ }^{5}$ Mayores antecedentes sobre las implicancias sociales y culturales de los bailes religiosos que asisten a La Tirana en Henríquez Rojas 1996; Laan 1993; Van Kessel 1988.

${ }^{6}$ Núñez Atencio 1989. Una segunda edición corregida y aumentada fue publicada en el año 2004. Una de las hipótesis planteadas por Núnez sugieren la profundidad histórica de la fiesta, la cual estaría vinculada a la extracción de plata en las minas de Huantajaya y Santa Rosa durante el período colonial. 
Este artículo retoma los apuntes esgrimidos por Núñez $(1989,2004)$ sobre los promeseros y bailes en La Tirana, pero se delimita a la cuadrícula de los demonios danzantes que han permanecido al margen de la orgánica de las cofradías y del disciplinamiento diocesano, como lo constituye el caso de los diablos sueltos. Estos bailarines, amén de su devoción religiosa, han mantenido el viejo principio de la autonomía desde su faceta interpretativa en la escenificación de la danza ${ }^{7}$. Asumen el rol de "figurín" en un plano performativo y metafórico ${ }^{8}$, como parte de las representaciones en soportes sígnicos y en prácticas culturales indígenas que reinterpretaron los contenidos catequéticos durante el proceso de evangelización colonial.

Los diablos sueltos expresan en el circuito de la coreografía la alteración agencial del orden litúrgico y jerárquico como "las artes del disfraz político", ya sea con discursos ocultos como pose o discursos ocultos como práctica cultural en un ambiente religioso que a continuación se analiza ${ }^{9}$.

\section{LA VIRGEN, EL DIABLO Y EL CORPUS}

La devoción a la Virgen María se remonta a los inicios del cristianismo, pero sólo a partir del siglo $\mathrm{X}$ se genera un punto de inflexión en cuanto a su masiva devoción. En ese momento se produce un redireccionamiento desde el culto a los diferentes santos al fervor mariano, el que asume un protagonismo como prototipo del creyente y como símbolo de la cristiandad al ser considerada la Virgen como Madre de la Iglesia ${ }^{10}$.

De acuerdo con la tradición católica relativa a la religiosidad sobre la Virgen del Carmen, se sabe que unos eremitas que seguían la forma de vida de los profetas Elías y Eliseo se convirtieron al cristianismo durante la fiesta de Pentecostés. Levantaron un templo en honor de la Virgen María en la cima del monte del Carmelo, sitio en el que Elías vio la nube en que figuraba la fecundidad de la Madre de Dios. Estos religiosos, denominados Hermanos de Santa María del Monte Carmelo, pasaron desde Palestina a Europa en el siglo XIII. Su regla de vida religiosa fue aprobada por el Papa Inocencio IV en 1245, cuando Simón Stock era general de la orden ${ }^{11}$. El 16 de julio de 1251, la Virgen se apareció a Stock, a quien entregó un escapulario marrón que debía llevarse "en señal de consagración a Dios y a la Santa Madre”. A esta aparición mariana se la denominó como Nuestra Señora del

${ }^{7}$ Geist 1996.

${ }^{8} \mathrm{Al}$ respecto seguimos los enfoques teóricos propuestos por Turner 1974 y 1988 . En tal sentido, la performance corresponde al conjunto de expresiones corporales y sonoras que generan información sobre ciertos aspectos de la sociedad. En un campo interpretativo, se canaliza con un carácter indicial de las manifestaciones (religiosas en nuestro caso), permitiendo inferir episodios y significaciones olvidadas o invisibilizadas por algunos grupos sociales. Cf. Wilde y Schamber 2006.

${ }^{9} \mathrm{El}$ principio teórico de la "agencia" en los grupos subalternos supone las lecturas, reinterpretaciones, discursos ocultos y/o públicos y ajustes desde los propios sujetos, como respuestas ante las fuerzas hegemónicas del Estado, la elite o la Iglesia. Una discusión mayor en Scott 2000.

${ }^{10}$ Maldonado 1985:67.

${ }^{11}$ Lefebvre 1940:1556. 
Monte Carmelo y el escapulario se consideró como una imagen de salvación ${ }^{12}$. Tras la noticia, Inocencio IV bendijo el escapulario y otorgó además privilegios a los religiosos y a todos los cófrades consagrados a la Virgen del Carmelo. Estos últimos podían llevar los escapularios, lo que significaba que participaban de los méritos y oraciones de la Orden, aparte de esperar que la Virgen los librara del Purgatorio. Para ello debían ser fieles en observar la abstinencia, la castidad conforme a su estado y las oraciones mandadas por Juan XXII en la bula llamada Sabatina, publicada el 3 de marzo de $1322^{13}$.

El culto a la Virgen del Carmen en España desde la época medieval se encuentra asociado a las aguas. Es la patrona de la Marina de aquel país, por lo que su celebración tiene lugar en medio de procesiones marineras de barcos engalanados con flores, bandas de música y estruendosos petardos ${ }^{14}$. En Brasil el culto colonial de los esclavos negros vinculó a la Carmelita con Yemanyá (santa), y fue resemantizada por la orixa o santa de las aguas ${ }^{15}$.

A partir del influjo de la cultura religiosa medieval, la Virgen fue resignificándose como protectora contra el Maligno y como la salvadora de los condenados por la justicia humana o divina. Se levantaba a la Virgen como una escapatoria a la severa doctrina de la Iglesia en torno a la condenación por los castigos eternos $^{16}$. Un dato interesante lo constituye la expresión contenida en un misal previo al Concilio Vaticano II (1962), que saluda con júbilo el día de la fiesta de la Virgen del Carmen: "Diem festum celebrantes sub honore beatae Mariae Virginis: de cujus solemnitate gaudent Angeli..." ["Celebrando la festividad de la Sma. Virgen María, de cuya solemnidad se alegran los ángeles"] ${ }^{17}$. Si fuere así ¿de qué ángeles estaríamos hablando en un recuento histórico?

La tradición señala que de los varios ángeles que debían desempeñar una misión entre los hombres, uno se negó a cumplir el mandato divino y se rebeló contra Dios al pecar de soberbia y aspirar a su poder. El ángel llamado Satán ("adversario" en hebreo), fue castigado por la ira de Dios, ya que quiso escalar al cielo como la "estrella de la mañana" o "el portador de la luz". De ahí deriva la denominación de "Lucifer"18.

Con el paso de los siglos, la figura arquetípica de Satán como el que se oponía a los preceptos divinos, paulatinamente se transformó en la entidad que tentaba al hombre a diferentes placeres que el cielo no podía proporcionar. Siguiendo el análisis de los términos vinculados a la figura de Satán, Muchembled propone que la versión griega de la Biblia cambia el término Satán por el de "diablo", palabra que etimológicamente alude a "quien pone división". El distanciamiento de los mandatos de Dios, derivó en la figura de un ser que tentaba al hombre y lo desviaba del

\footnotetext{
${ }^{12}$ Callejo 1999:204.

${ }^{13}$ Lefebvre 1940:1557.

${ }^{14}$ Callejo 1999:204.

${ }^{15}$ Callejo 1999:205.

${ }^{16}$ Maldonado 1985:88.

${ }^{17}$ Lefebvre 1940:1557.

${ }^{18}$ Busto 2002:30.
} 
camino del bien, hacia los placenteros caminos que ofrecía "el maligno". Así se generó una categoría en la cual uno de los principales significados -o sememas- era el de un ángel caído con un poder sobrenatural, que causaba males a la humanidad que no lo adoraba o seguía ${ }^{19}$. Esta significación insidió en el vocablo griego "daimon" (diminutivo de "daimonion"), origen de la palabra "demonio", apuntando a un "mal espíritu” que causa daño a los hombres ${ }^{20}$. En otros términos, el diablo asumió diferentes categorías y significados dependiendo de los contextos y dogmas teológicos, tanto para la exégesis judía como la cristiana. Alcanzó su proyección como entidad opositora a los designios sagrados en el medioevo y en la cultura popular que se conjugó en diferentes creencias campesinas que sintetizaron la tradición local con los componentes religiosos del catolicismo de la época.

El demonio fue quien puso en duda los mandamientos de Dios, alterando la arquitectura de la fe en la cual la humanidad debía creer. Su figura da cuenta del desconcierto ante la estructura moral que impone la religión. De ahí que sea representado iconográficamente siguiendo los patrones del imaginario popular como una figura humana con cuernos, cuerpo velludo, salvaje en su actuar o asumiendo la representación del dragón al enfrentarse al arcángel San Miguel, como serpiente tentadora, como galán adinerado con dientes brillantes o como un macho cabrío ${ }^{21}$.

Con los años, el diablo se fue circunscribiendo a un ente opositor a Dios. Al mismo tiempo, fue caracterizado por la cultura popular como un ser que podía convivir con los hombres y también poseerlos según las creencias campesinas. Así, los aldeanos encontraron en el diablo una oportunidad, pese al miedo que les causaba, para satirizar (o satanizar) las estrictas normativas sociales y la vida cotidiana del villorrio medieval ${ }^{22}$.

En otro ámbito, la jerarquía religiosa fomentó en el campesinado la instrucción en el dogma, mediante la representación de pasajes bíblicos. También les hizo partícipes del despliegue escénico que requería la ritualidad católica en diferentes momentos del año litúrgico, incluso mediante la literatura, la teatralidad callejera o la sátira. Con la efervescencia popular que generó en las comarcas el cristianismo, muchos ritos paganos cambiaron el eje simbólico de la representación pública hacia lo grotesco o hacia la comicidad de las ceremonias. Para ello alteraron el contenido de los significados iniciales por los cánones eclesiásticos, como lo fue en el carnaval o en las procesiones ${ }^{23}$. En tal escenario, la imagen del demonio medieval aparece tanto en los juegos públicos como en las visiones cómicas de ultratumba o en las fábulas paródicas. Satanás se transforma en un portavoz de la ambivalencia de las opiniones no oficiales, de la santidad al revés, de la expresión de lo inferior y material, de la crítica al orden y de la voz popular actuada ${ }^{24}$.

\footnotetext{
${ }^{19}$ Muchembled 2006.

${ }^{20}$ Busto 2002: 24.

${ }^{21}$ Brisset 2002:302.

${ }^{22}$ Bajtin 2003.

${ }^{23}$ Bajtin 2003.

${ }^{24}$ Bajtin 2003.
} 
Uno de los ritos públicos de índole religioso más llamativos de este período lo constituyó la "Faestum sacratissimi corporis D. N. Iesu Chisti" o la celebración del Corpus Christi, actividad cúltica de adoración a la Eucaristía. Este rito solemne fue instituido en el año 1246 en Liège (Francia) y en 1264 en Roma por el Papa Urbano IV. Fue promulgado oficialmente en 1313 por Clemente V y se asumió rápidamente como una práctica generalizada en toda la cristiandad. Tempranamente Urbano IV estableció en el culto popular esta fiesta con la intención de que "las piadosas muchedumbres acudieran a las iglesias para enfervorizarse con la entonación de alegres himnos". Posteriormente el Concilio de Trento consagró esta celebración como el "triunfo de la fe sobre la herejía", de modo de erigir la Iglesia triunfante en una manifestación pública y masiva ${ }^{25}$. En un plano simbólico, tras la misa durante la fiesta de Corpus Christi, salía del templo una procesión encabezada por el obispo quien llevaba en el ostensorio el cuerpo consagrado de Cristo en la hostia. Recorrían las callejuelas de las aldeas en una ruta por los espacios profanos, con la devota intención de que todos los feligreses lo veneraran ${ }^{26}$. En la procesión, la comunidad estaba fraccionada en grupos que precedían o seguían al Santísimo, llevando cada hermandad o cofradía los respectivos emblemas o estandartes. En la procesión sacra se representaban los diferentes segmentos de la sociedad, ya sea con lujosos trajes o con disfraces, simulando los pecados que rodeaban la vida cristiana medieval.

Entre el misterio de la fe, el Corpus se constituyó como una de las festividades más populares de toda la cristiandad. Sin lugar a dudas el eje articulador fue la procesión con el Santísimo, sintetizando desde la hibridez cultural la religiosidad y el protocolo civil. Durante esta fiesta, el mundo salvaje acecha a la comarca que es bendecida por la Custodia Sagrada. Así, diversos animales como dragones, águilas, bueyes, leones, etc., desfilan en el perímetro de la romería como una zoología mística ${ }^{27}$. Del mismo modo, Corpus Christi fue proclive a la generación de expresiones teatrales más del gusto pueblerino ${ }^{28}$. A modo de ejemplo, se realizaban representaciones de diablos danzantes que simularon la lucha con el arcángel San Miguel, el cual triunfaba después de una teatralizada refriega ${ }^{29}$. La denominación hispana para estos actos medievales fue la "endiablada". Acerca de este término se cuenta con referencia documental para el año 1583 la que alude al "festejo y función jocosa en que muchos se disfrazaban con máscaras y figuras ridículas de diablos" ${ }^{30}$. En 1635 sobre la fiesta de Corpus en Granada se informó que a las "tres de la tarde comenzó a formarse la Procesión, a que daba principio la danza, que llaman de los diablillos, que con sus horrorosas figuras, golpes y estruendo, espantando la gente, hacían calle para dar paso a la tarasca (que) ponía terror, y causaba miedo a el verla, escoltada de ocho horribles gigantes (a quienes seguía

\footnotetext{
${ }^{25}$ Romero 1999:87.

${ }^{26}$ Macherel 1999:49.

${ }^{27}$ Callejo 1999:133.

${ }^{28}$ Sans 2007.

${ }^{29}$ Callejo 1999:133.

${ }^{30}$ Brisset 2002:302.
} 
una torre portátil coronada por la virginal imagen) custodiada por un escuadrón de setenta y dos ángeles, niños de nueve y diez años, con una pica y un escudo en las manos"31.

La misma escena se repite en Sevilla hacia fines del siglo XVIII. José Blanco White (1822) describió entonces el Corpus Christi como:

"Único día del año en que la hostia consagrada es puesta por la calle. A poca distancia... venía un grupo de siete gigantescas figuras (...) Detrás de los gigantones y como dominándoles, venía un paso con la figura de una hidra rodeando un castillo del que, para delicia de los niños sevillanos, salía un muñeco parecido a Polichinela y vestido con un jubón escarlata guarnecido de cascabeles. El muñeco bailaba una especie de danza salvaje y se volvía a ocultar en el cuerpo del monstruo. Esta representación llevaba el nombre de "Tarasca". Los gigantes simbolizaban los siete pecados capitales. La hidra representaba la herejía, guardiana del castillo del cisma en el que la locura (representada por la extraña figura de escarlata) desplegaba el dominio completo. Todo este tropel de monstruos iba huyendo en desbandada delante de la presencia del triunfante sacramento"32.

La teatralización de los actos en la procesión del Corpus editó la imagen de numerosos diablos en comparsas llamadas "endiabladas". Ellas representaron los males a los que se exponía la humanidad cuando se distanciaba de los preceptos divinos, como lo constituían los siete pecados capitales. En Europa fueron también conocidos como "ball des diables", integrados por cuadrillas de hombres disfrazados de demonios, quienes entre polvorines y fuegos de artificios presentaban diálogos compuestos en versos, además de acompañarse por el sonido de los tambores ${ }^{33}$. Estos conjuntos lo integraban personajes como San Miguel, Lucifer, un ángel, una "diabla" y distintos diablos. Los "ball des diables" se vincularon sobre la base de los versos a las antiguas teatralidades de los siete pecados capitales ${ }^{34}$.

Con la performance de las cofradías y el decálogo contendido en aquellos actos religiosos propios del teatro callejero barroco -pese a la sátira representada por los diablos- estas organizaciones se constituyeron en "pequeñas iglesias”. En ellas se establecía la reconciliación entre el cuerpo social y la vida mística ${ }^{35}$, la cual era predicada con claridad y sencillez desde la curia diocesana tanto en Europa como en América ${ }^{36}$.

\footnotetext{
${ }^{31}$ Fray Juan de la Natividad Coronada Historia... imagen de la Virgen de Gracia en convento Trinitarios, Granada, 1697 citado por Brisset 2002:305.

${ }^{32}$ Callejo 1999:135.

${ }^{33}$ Campmany 1946:5.

${ }^{34}$ Fortún 1961:6.

${ }^{35}$ De Certeau 2004:106.

${ }^{36}$ En España aún en algunos poblados siguen celebrando fiestas acompañándose las expresiones religiosas con la figura del demonio, tal como acontece en Algaida (Mallorca), Arta (Mallorca), Almonacid del Marquesado (Cuenca), Huete (Cuenca), Castejón de Monegros (Huesca), entre otras localidades. Cf. Callejo 1999.
} 


\section{EL DIABLO ANDINO / COLONIAL}

En Europa se propagó la imagen del diablo con dos variables significantes -el maligno causante de la tentación y la muerte del alma o la sátira para enjuiciar mediante la burla las diferencias sociales. Del mismo modo en la América conquistada el rostro del demonio recorrió sus diferentes geografías. Los misioneros utilizaron la predicación implícita en la liturgia, la influencia del canto sagrado, las festividades a los santos, al arcángel San Miguel, la devoción a la Virgen y/o las procesiones como complemento a otros formatos catequéticos, como fueron los himnos o las imágenes en los templos que actuaban como "sermones silenciosos" para cautivar la espiritualidad de las poblaciones nativas. Un dato no menor lo constituyó el uso del teatro religioso. Su tendencia a reproducir pasajes de la Biblia o ritos medievales sirvió para evangelizar a los indios, que participaron como actores en el montaje de las escenas, las que en ocasiones fueron escritas en la lengua de los aborígenes ${ }^{37}$.

En Potosí (Bolivia) en 1601 se realizaba una escenificación de la lucha entre ángeles y demonios para la celebración de las festividades en honor a la Virgen de Guadalupe. En esta obra aparecen como personajes centrales, entre otros, Lucifer, una sirena, la Virgen y un caballero cristiano. Este último debía enfrentarse al demonio para reclamar la belleza de María o Proserpina (sirena). Esta disputa era evaluada por un jurado que dictaminaba quien era el vencedor. Asimismo todos los personajes principales y secundarios eran recibidos con disparos de artillería y cohetes. La información del siglo XVII describe que el montaje se iniciaba con la salida de:

"muchos demonios en caballos muy ligeros, todos con ropas negras y llamas de fuego (...) Salió luego... un carro triunfal., el cual tiraban cuatro sierpes, con las cuales iba un demonio... en la mano derecha venía sentada Proserpina, el rostro... muy blanco y hermoso... y del medio cuerpo para debajo de sierpe y con la cola rodeaba el carro" 38 .

Este relato, y otros que es posible encontrar en la bibliografía sobre el tema religioso durante la Colonia, grafica la hipótesis de que la cultura religiosa europea fue reproducida en América. Fue como una oleada de los imaginarios populares que encontraron en las sociedades nativas los contextos para implantar el modelo religioso medieval. El teatro religioso presente en los montajes de los "autos sacramentales", que eran escenas alegóricas de los dogmas católicos como el Corpus, actuaron como dispositivos ideológicos de la Iglesia e impusieron la doctrina en la conversión de los indígenas con el uso de los dramas acerca de los pecados capitales, los ángeles y demonios ${ }^{39}$.

Mientras Europa en el siglo XV paulatinamente cambiaba hacia una impronta renacentista, los aborígenes amerindios recibían el influjo cultural de aldeanos con

\footnotetext{
${ }^{37}$ Ricard 2004.

${ }^{38}$ Gisbert 1999:244.

${ }^{39}$ Calvo Pérez 2001.
} 
una mentalidad tradicional que se habían enrolado en las huestes conquistadoras. Ellos trajeron consigo el culto público a los santos, al Corpus Christi, la devoción a la Virgen, el carnaval y el miedo al diablo o a "San Tanás", como fue resignificado entre los nahuas en Mesoamérica ${ }^{40}$.

Si fue así, entonces América podía contener la piedad popular, mientras los territorios europeos abrazaban el espíritu humanista y el advenimiento del protestantismo que no creía ni en imágenes ni en los disfraces de la feligresía. En América, en tanto, se reprodujo la imagen del diablo, ya sea en las conciencias colectivas como en las expresiones artísticas. El demonio fue reeditado con los atributos que el mundo popular europeo le había asignado, con cuernos, rostro de hombre con elementos de un macho cabrío, una cola y la sagacidad en su actuar. De igual forma, las misas en las plazas y las romerías como parte de las muestras públicas del culto católico formaron también parte de las campañas de evangelización. En tal sentido, los indios se vieron integrados en todos estos actos de piedad religiosa. Participaron como cargueros de las imágenes de los santos, como músicos de letanías en los templos o como danzarines a Corpus Christi o a la Virgen. Ellos conjugaron una multiplicidad de creencias tanto autóctonas como cristianas, tal como sucedió con las imágenes de la boca del infierno o "tarasca" dibujada en Europa, en los Andes y en Parinacota (altiplano de Arica) ${ }^{41}$.

Puntualizando, en el área andina los indígenas percibieron en el diablo una figura ambivalente en cuanto a su poder. Podía generar maldad o hacer el bien, lo que permitió no sólo temerle a su asedio como acontecía en Europa, sino que incluso fue posible para los indígenas dialogar con el demonio como lo hacían con sus wakas, ídolos o antepasados. Por esta razón, los cronistas vincularon las pláticas de los indios y las wakas con los oráculos de Lucifer tal como se visualiza en las siguientes imágenes (ver imágenes $\mathrm{N}^{\text {os }} 1,2,3,4$ y 5).

${ }^{40}$ Busto 2002.

${ }^{41}$ En Lima el Concilio de 1551 construyó una horrorosa imagen del diablo para que los indios la asimilaran, al decir que "el infierno es la morada de los demonios, donde van aquellos, los que no han sido bautizados, o los que no respetan los mandamientos". Cf. Duviols 1997:41. 


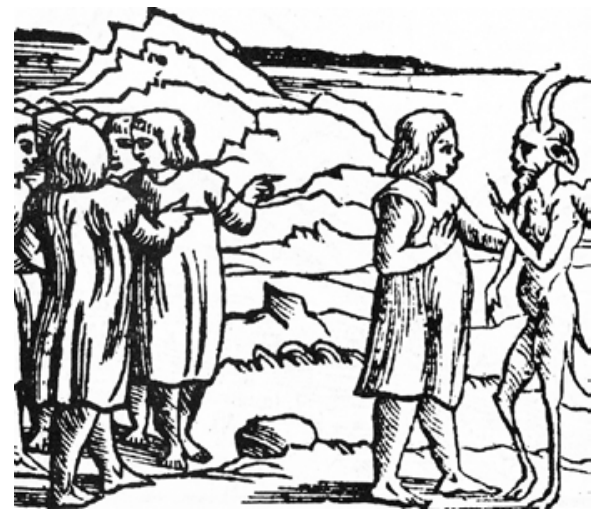

Imagen $\mathrm{N}^{\circ} 1$

"Los indios conversan con el demonio", el cual posee características humanas y de macho cabrío

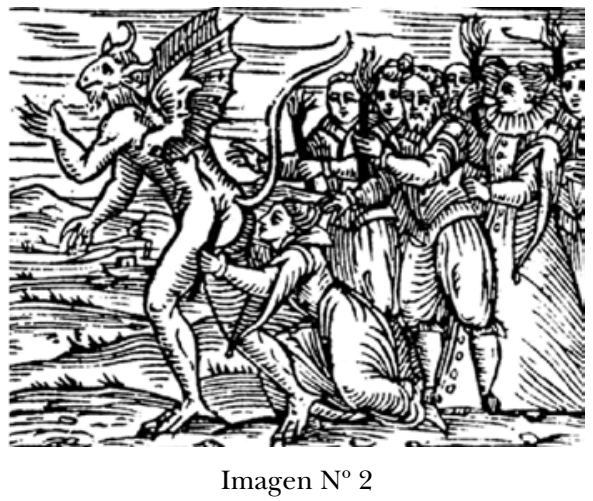

La estampa medieval del diablo perseguido por aldeanos (Muchembled 2006).

(Cieza de León $(1553)^{42}$.
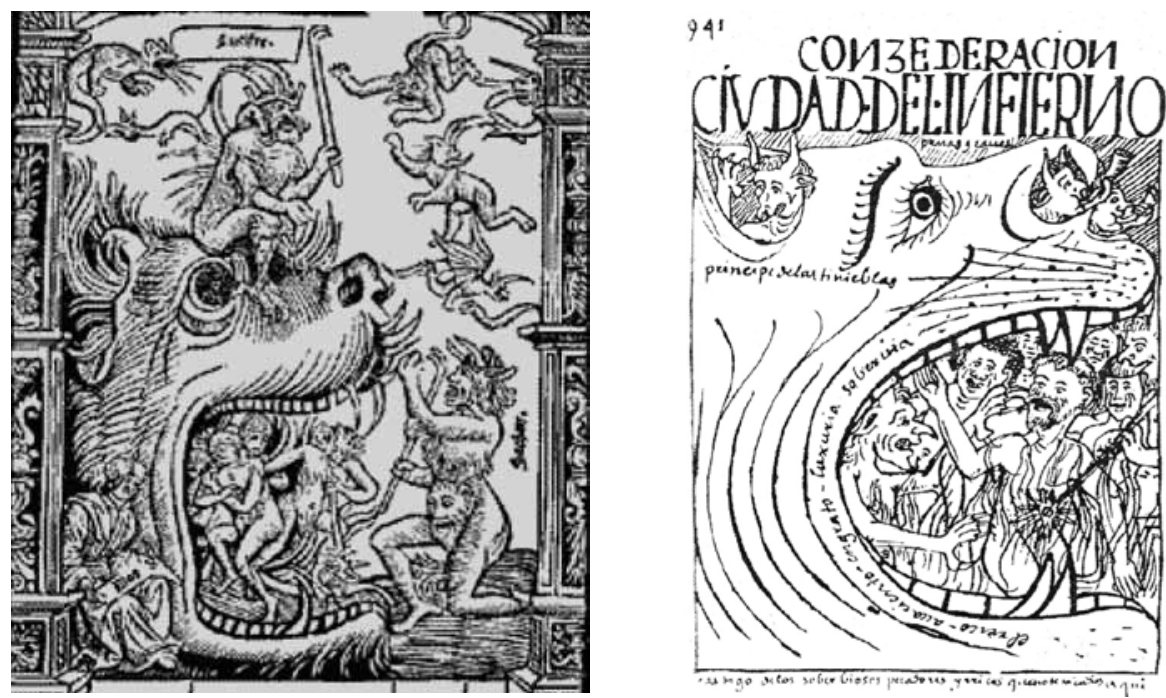

Imágenes $\mathrm{N}^{\circ} 3$ y 4

La boca del infierno o "tarasca" tanto en ilustraciones medievales como mestizas andinas, como lo constituye el caso de Guamán Poma (1615). En ambas imágenes la figura del diablo posee atributos antrópicos y animalescos.

${ }^{42}$ Cieza de León 1553 [1880]. 


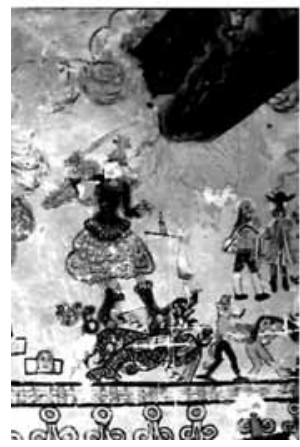

Arica (Chacama 2009).

En esta fotografía se ilustra la teatralización de la "tarasca", en la que los personajes centrales visten trajes y máscaras de diablos, españoles y de San Miguel (detalle). La catequesis de los indios operó tanto en formato de imágenes como en la teatralización de las creencias y los dogmas ${ }^{43}$.

Es evidente la ascendencia europea en este tipo de manifestaciones religiosas que involucraron trajes, coreografías y músicas. La celebración del Corpus fue el dispositivo que logró articular las escenas litúrgicas al interior de la aldea. Esta influencia socio-religiosa europea y el diablo como un mecanismo de alteración del orden imperante (cívico y religioso) se propagó por diferentes latitudes. A modo de ejemplo se puede mencionar un caso en La Serena, en 1752, lugar donde se describió que,

“en la procesión del Corpus se exhibían catimbados, hombres vestidos de caprichosos trajes, simbolizando al diablo; empellejados hombres también cubiertos de pieles que son brazos y aves muertas jugaban malas pasadas a los niños". ${ }^{4}$

Los ritos colectivos, tanto sagrados como profanos, fueron asumidos por los distintos segmentos sociales de la Colonia. En otras palabras, las procesiones eran barómetros que permitían tomar el pulso al comportamiento y posición en la estructura societal de los diferentes grupos -oligarquía, clérigos, artesanos, mestizos, indios, zambos, mulatos y/o negros. Estos grupos seguían el orden asignado a cada cofradía en la columna.

En Santiago y en Lima desfilaban para el Corpus los feligreses con trajes, "mascaradas" y carros decorados, representativos de episodios religiosos como

${ }^{43}$ Es necesario consignar que estas premisas obedecen a hipótesis de trabajo que aún están en un proceso de análisis. No obstante, prontamente se publicará in extenso un estudio sobre la imagen, las cofradías y la teatralidad en los Andes chilenos. Una discusión exhaustiva sobre el rol de la imagen en las campañas de evangelización se encuentra en Chacama Rodríguez (2009).

${ }^{44}$ Enrich 1891:133. 
las tradicionales "tarascas" o los enfrentamientos entre ángeles y demonios. En las principales ciudades de la América colonial, el uso de carros con la parafernalia decorativa y el sonido de tambores no sólo sirvieron para el evento católico, sino que también para el recibimiento triunfal de las autoridades virreinales ${ }^{45}$.

En festividades populares como el carnaval, algunos campesinos en Copiapó vistieron los atuendos de diablo para alterar el orden cívico como posible respuesta subalterna. A modo de ejemplo, en el verano de 1866 la prensa describió lo siguiente:

"la destreza en el echar la ligereza en el huir i la zalagarda de todos formaban en el barrio una verdadera babel. También se veía una especie de comparsa, formada de varios seres del sexo feo, que precedidos por un tamborcito, marchaban de a dos en fondo, vestidos de máscaras i el jefe de diablo. Era el diablo un poco circunspecto, [...] vestía de colorado, con uñas y rabo, penetraba en las casas i después de dar sus órdenes la comparsa ejecutaba una danza cuyo nombre no hemos hallado en el diccionario. Aplaudían las niñas, saludaban las máscaras, i se iban con la música a otra parte. Si de las calles públicas le fuera dado al cronista penetrar en el interior de las casas, que de cosas tendría que contar. Allí ejerce el carnaval su imperio con más encantos, con más gratas sensaciones. Las bellas i los mozos rivalizando en delicadas i atrevidas intentonas de asalto, se confunden por último en el ardor de la lucha, i la modesta azucena, la cándida sensitiva se lanzan tras del nerbado varón i lo zambullen en el no muy cristalino depósito de agua. Desde entonces sesan las etiquetas preliminares i el asunto es ni más ni menos como en la calle" ${ }^{46}$.

Volviendo al área andina, se cuenta con la referencia a diablos que participaban en este tipo de celebraciones litúrgicas actuando como bufones que "fastidiaban" a los feligreses, como las fuerzas del mal que rondan los campos o caseríos, similar a la jovial estampa del diablo para el tiempo de "carnestolendas".

A fines del siglo XVIII, en Tacna sucedió un altercado producido por un negro disfrazado como demonio. El episodio fue descrito de la siguiente manera:

"Señor Governador. Intendente. Don Francisco Salguero vecino de esta cuidad en nombre de Don Francisco de Zela ensayador, Fundidor y Balansario de las Reales Caxas del Pueblo de Tacna y en virtud de su poder que devidamente presento como mejor proseda paresco ante S Señoria y Digo: que el Juebes de Corpus que se contaban treinta de Mayo de este presente año, un Negro Esclabo de mi parte salio con Bestuario de Diablo, y corriendo por las Calles y Plasa haciendo en ellas las marisquetas, y gestos que el traje requiere, encontró con un sambo esclabo de Doña Juana Oportu, el que lo incomodó, y asercandose el Esclabo de mi Parte le dio un empujo el que fue bastante para el sambo se echase sobre el y lo maltratase con crueldad. Mi parte innorante de este pasage lo estubo tambien de que el Alcalde Ordinario del referido Pueblo Don Pablo Gila havia mandado encarselar al Negro a un constandole por las constituciones de la Cara, y sangre en que estava bañada que el Esclabo de la Oportu lo havia erido con exeso, hasta que asía las dote se le comunicó noticia poco instructiba de lo que ba referido, y para mejor uniformarte

${ }^{45}$ Valenzuela 2001.

${ }^{46}$ Periódico El Copiapino, 26 de febrero, 1868, citado por Godoy 2007. 
de ello pasó mi parte personalmente a Casas del Mensionado Alcalde, y entrando con urbanidad, y cortesia, despues de una corredida salutacion le preguntó qual era la causas de haber encarselado a su Esclabo- La contestacion del Alcalde fue asercandose a mi parte desirle, que era un sambo Limeño borracho" ${ }^{47}$ (cursiva agregada).

La descripción a la cual alude el documento se refiere, pese al bochorno entre el esclavo y el zambo, a la danza del "son de diablos". Este baile era interpretado por indios o por población negra, quienes enmascarados recorrían los perímetros de los actos públicos devocionales realizando ágiles movimientos con sus capas, además de dar numerosos "saltos" entre la muchedumbre de creyentes. Este tipo de danza fue ilustrada en Lima a comienzos del siglo XIX por el pintor peruano Pancho Fierro, tal como puede verse en la siguiente acuarela (ver imagen $\mathrm{N}^{\circ} 6$ ).

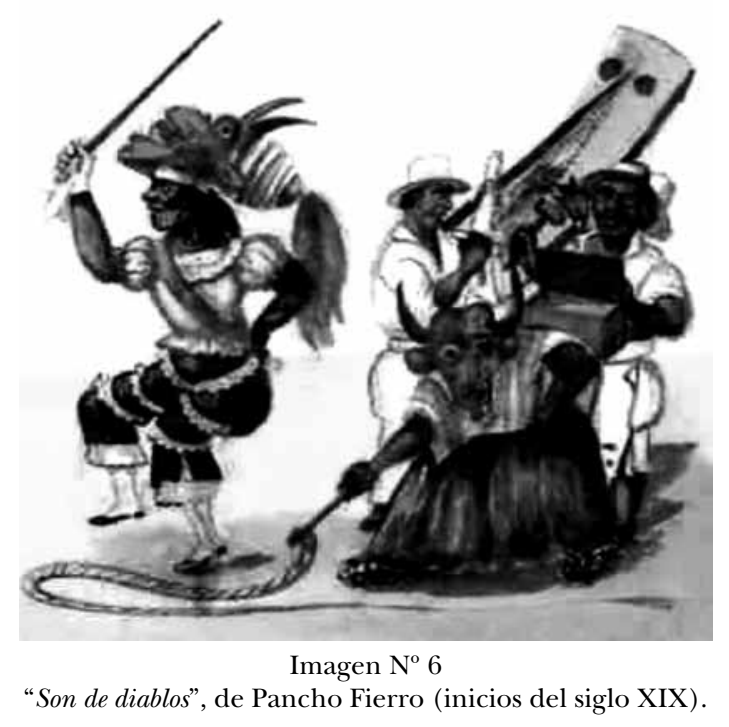

Al norte del Perú, el obispo de Trujillo, Baltasar Martínez Compañón, mandó a dibujar todas las expresiones sociales y religiosas de su diócesis, bosquejos que retrataron los distintos segmentos de la sociedad peruana hacia 1776 . Una de sus acuarelas reproduce una danza europea adaptada por los indios, en la cual se grafica un baile en el que se enfrentan el arcángel San Miguel frente a siete demonios, la que es localmente como la "Danza de los Diabilicos". A continuación reproducimos la estampa $\mathrm{N}^{\circ} 145$ (ver imagen $\mathrm{N}^{\circ} 7$ ).

${ }^{47}$ Biblioteca Nacional del Perú (BNP), Libros raros y manuscritos 1793: fojas 2 - 3. La cursiva es nuestra. Agradezco la gentileza del historiador Julio Aguilar Hidalgo por facilitarme este documento. 


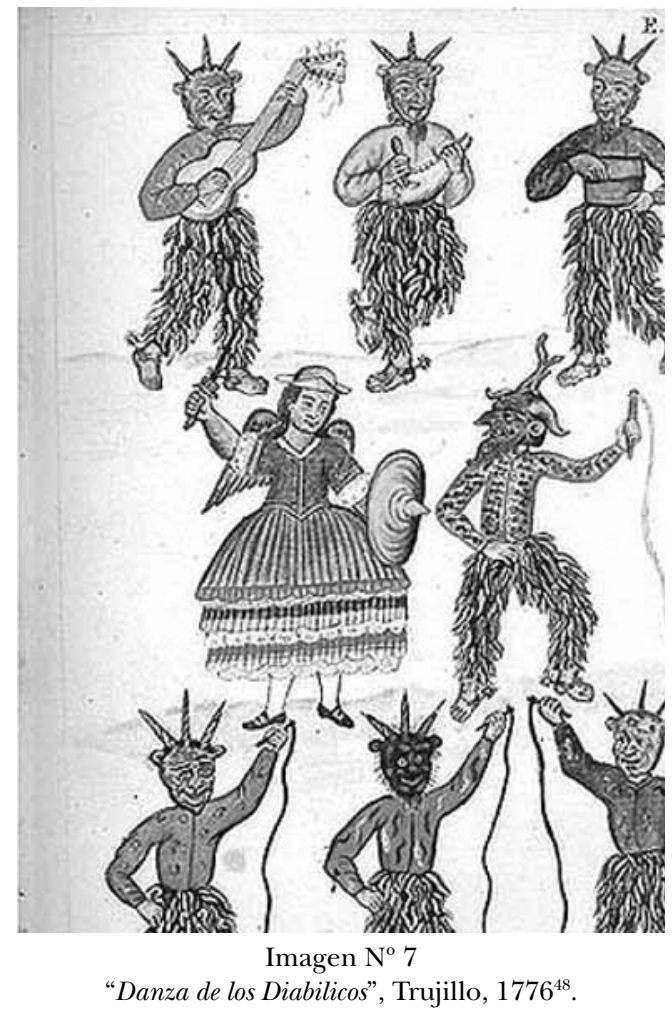

Existen antecedentes que confirman la influencia colonial en las danzas que se interpretan en las procesiones y festividades de santuarios. No obstante, es oportuno identificar algunos tópicos que poseen raíces autóctonas andinas las que ciertamente han incidido en los patrones cosmogónicos de las expresiones rituales que se desarrollan en las poblaciones indígenas.

Algunas de las celebraciones religiosas católicas que se implementaron en el área andina, como las misas, las procesiones o el culto a los santos, contuvieron tanto en su representación como en el contenido simbólico ciertos elementos propios de los grupos indígenas. De acuerdo con nuestro planteamiento, la celebración del Corpus Christi permitió que se articularan tanto las creencias cristianas como las andinas, con matices complejos de acuerdo con contextos y experiencias históricas ${ }^{49}$. En relación con la fiesta al Santísimo Sacramento los extirpadores de idolatrías identificaron que los indios llevaban durante:

${ }^{48}$ Martínez Compañón y Bujanda 1776 [1987-1991].

${ }^{49}$ Los concilios limenses del siglo XVI estipularon que en la fiesta del Corpus Christi los indios podrían estar celebrando creencias nativas; la constitución $\mathrm{N}^{\circ} 95$ señala que "en las fiestas del corpus xpi. $Y$ en otras, se recaten mucho los curas y miren que los indios fingiendo hacer fiesta de xpianos no adoren ocultamente sus ídolos y hagan otros ritos, como acaece, y si en algunos se describe semejante maldad hecha la información necesaria, se embie preso al obispo o a su vicario para que le castiguen con todo rigor". Trujillo 1981: 327. 
"la procesión del Corpus dos corderos de la tierra vivos (llamos), cada uno en sus andas, por vía de fiesta y de danza, y se supo que realmente eran ofrendas y sacrificios ofrecidos a dos lagunas que son Urcococha y Choclococha, de donde dicen que salieron y tuvieron origen las llamas. Y ha llegado a tanto esta disimulación o atrevimiento de los indios, que ha acontecido poner en la fiesta del Corpus una huaca pequeña en las mismas andas al pie de la custodia del Santísimo Sacramento, muy disimuladamente. Y un cura me dijo que había hallado las huacas en el hueco de las peanas del altar y otras debajo del altar, que las había puesto el sacristán, y yo las he visto detrás de la misma iglesia" ${ }^{50}$.

Los ídolos escondidos entre los altares cristianos simbolizaban la hibridez de una mentalidad religiosa en permanente transformación. Para los teólogos coloniales el ángel caído se había refugiado en América, lugar en que era adorado por los "infieles" nativos. Según se señalara anteriormente, podía platicar con los indios utilizando a las wakas o "ídolos de la gentilidad" para comunicarse, o mediante los sueños, poder apoderarse de las almas o los cuerpos. De acuerdo con esta lógica, el diablo podía adquirir diferentes formas con igualmente diversos atributos:

"Es frecuente que tenga un aspecto terrible o repulsivo, la tez cenicienta, violácea, cavernosa la voz. Aparece a veces como un indio de poca estatura, o como un pequeño negro, y hasta como un inca. Puede vestir andrajos, o ropas multicolores. Hasta con apariencia humana tiene patas y garras de león, de oso, o bien, espolones de gallo. (...) Las múltiples metamorfosis pueden ser muy rápidas, y su acción es aun más temible porque sus innumerables servidores, los otros demonios, poseen sus mismas facultades" $"$.

El demonio con su capacidad persuasiva y de metamorfosis fue estereotipado por los evangelizadores como un ser difusor de las idolatrías de los indios, que adoptaba las formas y voces de los antepasados para engañarlos en sus acciones. El cura doctrinero de Sabaya, localidad cercana a Isluga (Tarapacá), Bartolomé Álvarez en 1588 exclamaba que:

"El demonio les decía a los indios, que él (el demonio) era un antepasado y que cuando ellos (los indios) no lo fuesen a visitar, adorar y otorgar dones él se enojaría haciendo que algún pariente o hermano muera. (...) Para que los indios mochasen (adorar, ofrendar) el demonio les dijo que lo hicieran en un sepulcro donde él estaba enterrado, aquello podría ser un peñasco o lugar dificultoso, una piedra" ${ }^{52}$.

Igualmente, los indígenas andinos tenían por devoción el culto a diferentes animales o especies a las cuales "mochaban" u ofrendaban bienes preciados, como coca o chicha. Al respecto, conviene agregar que:

\footnotetext{
${ }^{50}$ Arriaga 1621 [1968]:223.

${ }^{51}$ Duviols 1997:28.

${ }^{52}$ Álvarez 1588 [1998]:76.
} 
"Los indios adoran lagartijas, lagartos, culebras, víboras y mariposas, de los que tenían figuras (diseños) pintadas en vasos y ropas. Todo esto es superstición puesto que son animales que miran y rondan en los sueños" ${ }^{2}$.

Los antecedentes del cronista Garcilaso de la Vega en el siglo XVII confirman estas aseveraciones, al señalar que:

"También tenían por dioses a otras culebras menores, donde no las había tan grandes como en los Antis; a las lagartijas, sapos y escuerzos adoraban. En fin, no había animal tan vil ni sucio que no lo tuviesen por dios" ${ }^{\prime 54}$.

Tales antecedentes nos permiten vincular la imagen del demonio con dos evidentes supuestos. Ellos son, por una parte, el hecho de conversar con los achachis o antepasados de los indios y, por la otra, la devoción de éstos a los animales como serpientes, culebras y sapos. En otras palabras, hay un espacio semántico que indudablemente posee la naturaleza salvaje para que sea relacionada con el demonio. Donde mora la razón, las leyes, la disciplina (en la ciudad o la iglesia) el diablo no puede habitar. No obstante, en los sitios en que convive lo bárbaro con lo peligroso como es el paisaje andino, sí fue un lugar propicio para que Lucifer levantara sus dominios.

El cronista mestizo Guamán Poma ilustró el acecho salvaje del que era víctima el cristiano. Para ello detalló por medio de la imagen dichas conjeturas.

“694

POBRE DE LOS IN[DI]OS: DE SEIS ANIMALES Q[VE] COME que tememen [sic.] los pobres de los yndios en este rreyno.

/ corregidor, cierpe / 'Ama llapallayque llatanauaycho'

['No me despojen por amor de Dios; te voy a dar más.']

/ Por amor de Diopsrayco / tigre, españoles del tanbo [mesón]

/ león, comendero / zorra, padre de la dotrina / gato, escriuano

/ rratón, cacique prencipal / Estos dichos animales, que no temen a Dios, desuella a los pobres de los yndios en este rreyno y no ay rremedio. / pobre de Jesucristo /

/ Ama yapallayki llat'anawaychu. / Diosrayku / tanpu" ${ }^{55}$

Los cronistas relevaron información valiosa sobre los seres que adoraban los indios en el mundo andino, como "lagartijas, lagartos, culebras, víboras, sapos y escuerzos". Estos animales pertenecen a la entidad cosmogónica "salqa", que traducido del quechua significa "salvaje". Todos los indios que no han abrazado la religión oficial, la moral y sus normas están en estado salvaje, alejados del nuevo ordenamiento que trae consigo la cultura y la mentalidad religiosa occidental.

Desde un punto de vista misional, es factible argumentar que en el universo de los "salqa" el demonio encontró un territorio llano para habitar y congregar

\footnotetext{
${ }^{53}$ Álvarez 1588 [1998]:80.

${ }^{54}$ Garcilaso de la Vega 1984: 21.

${ }^{55}$ Guamán Poma de Ayala 1615 [1992]:694.
} 


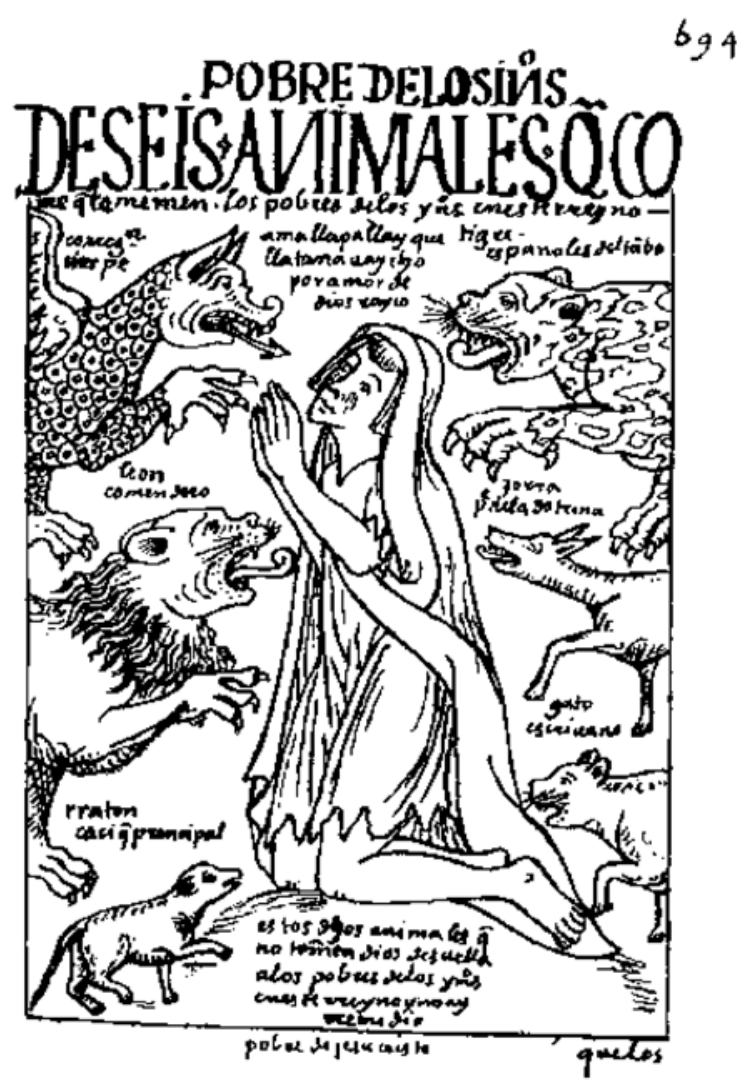

a sus seguidores. Este "mundo de abajo" o "mundo de adentro" como lo llamaron los evangelizadores, catalizado por los indios como "manqha pacha" (aymara) o " $u k h u$ pacha" (quechua), fue un espacio en el que gobernó el diablo conocido como "saxra" o "saqra" en el idioma de los inkas. Algunos teólogos coloniales señalaron que la expresión "manqha pacha" correspondía al infierno, aunque esta codificación en la cosmovisión andina posee la dualidad de ser un espacio a veces maligno y otras veces benévolo ${ }^{56}$.

El término andino utilizado para referirse al demonio ha tenido dos vertientes: "saxra" y "supay". La expresión "saxra" o "saqra" define al diablo, asignándoseles acepciones de "miserable, perverso y vil". La denominación más conocida es la de "supay", traducido por los curas doctrineros bajo la categoría europea de demonio o diablo ${ }^{57}$. Diego Gonçalez Holguín (1608) registró diablo como: “Cupay, cupayruna: Maldito malísimo endiablado, o cupaypa hucnin, Diabolico cupay hina cupay ñirac" ${ }^{58}$.

\footnotetext{
${ }^{56}$ Albó 2002.

${ }^{57}$ De Torres 1619.

${ }^{58}$ Gonçalez Holguín 1608:308.
} 
En el mismo período el jesuita Ludovico Bertonio (1612) apuntó los siguientes significados:

\section{"Supayo: Demonio}

Supayona allcomaata haque: Hombre endemoniado, o como endemoniado, o furioso, que por otro nombre llaman, Loqhuetiri haque. Y suelen a vezes andar por los cerros... Huakana allcomaata haque: Un hombre a quien hablo el Demonio, o Idolo, mandandole algo, o enseñandole el modo de sacrificar, y otras hechizerias.

Supayona maluta, y el Mantata haque: Endemoniado al modo que agora entendemos los Christianos" ${ }^{\prime 2}$.

Asimismo Bertonio desarrolla una interesante asociación del "supay" con algunas expresiones de danzas en fiestas autóctonas y con la presencia de personajes disfrazados de diablos o semejantes a ellos:

"Demonio: Supayo: Antiguamente dezian: Hahuari, que es fantasma: Endemoniado: Supayonamaluta, vel Alcomaata haque.

Demoñuelos, o Diablillos de las danzas: Sokho, Sancatilla, Culueulan, Saynata, Llama llama, Haachnen"60.

Sobre las danzas en las que participaban diablillos identifica:

"Sokhatha, u el Aymatha: Baylar la gente principal, y cantar con mucha mesura.

Sokha, u el Ayma. El bayleassi, o sarao de Maycos.

Sokho, Sancatilla, Llama llama, Culunculo, Saynata. Espantajo de niños, mascara fea, o mala cara.

Sokhochasitha. Enmascarase Vide Saynatachasitha" ${ }^{61}$.

Los apuntes del Vocabulario de la lengua Aymara sobre danzas y máscaras de diablos son coherentes con los ritos descritos por los cronistas tempranos. Ellos constataron que:

"aunque sacrificar reces y otras cosas, que no pueden esconderse de los españoles, las han dejado, a lo menos en público, pero conservan todavía muchas ceremonias que tienen origen destas y supersticiones antiguas. Por eso es necesario advertir en ellas, especialmente que esta fiesta de Ito la hacen disimuladamente hoy en día en las danzas del Corpus, haciendolas las danzas de Llama - llama y de Guacones y otras conformes a sus ceremonias antiguas, en los cual se debe mirar mucho"62.

A comienzos de la colonización los evangelizadores proyectaron la impronta cultural ibérica en los territorios andinos, junto con codificar una serie de prácticas cúlticas o festivas nativas con la experiencia religiosa europea. Estas experiencias

\footnotetext{
${ }^{59}$ Bertonio 1612:328.

${ }^{60}$ Bertonio 1612:170.

${ }^{61}$ Bertonio 1612:322.

${ }^{62}$ De Murúa 1590 [1946]:342.
} 
análogas fueron construyendo imágenes sobre un mundo andino que poseía elementos propios a los cuales se les reasignó una infinidad de variables semánticas que buscaron explicar lo "autóctono" desde un prisma europeo. En este traslape de asignaciones semánticas se generaron connotaciones interpretativas sobre bailes indígenas como el "Llama Llama", en el que se dedicaban "ofrendas y sacrificios ofrecidos a dos lagunas que son Urcococh a y Choclococha, de donde dicen que salieron y tuvieron origen las llamas". Esta ceremonia se reactualizaba cada año para la fiesta de Corpus Christi. Durante los ritos en honor a las llamas, los indios danzaban y vestían atuendos y máscaras similares a los diablos, lo que asustaba a los participantes, según la información recopilada por Ludovico Bertonio y Diego Gonçalez Holguín respectivamente:

Ludovico Bertonio (1612):

"Llamallama, Haachuco: Mascara o diablillo q sale en las danzas ${ }^{63}$

Saynata, Soktho, Culunculun, Llama llama: Espantajo, o mascara para espantar los niños.

Saynatachasitha, Sokhochasitha... Disfrasarse como espantajo ${ }^{64}$

Mascara: Sokhovide Espantajo. Ponersela Sokhottasitha"65.

Diego Gonçalez Holguín (1608):

"Llama hina runa: Hombre animal, o bestial sin juizio rudo.

Llama llama hamarracho: Enmascarado, o dos uno sentado en los hombro de otro ${ }^{66}$ Hayachuco llamallama saynata huacon: Los que hacen juegos o danzas disfrazados" ${ }^{67}$.

De múltiples formas, entre danzas, máscaras y ritos, la figura arquetípica del "supay" resemantizada durante la Colonia como diablo ("yawlu”), Lucifer, Satanás o el demonio, tomó distancia de su conexión con el concepto andino de "sombra", o sus asociaciones con "japiñuño, " nanqha”, "visscochu”, "anchanchu”, "bumapurick", como demonios que residen en "supayhuasi" o la "casa del demonio", popularizada también como el infierno. Las relaciones generadas entre los indígenas y los demonios se fueron reconfigurando socialmente sobre la base de la estructura de intercambio, tal como sucede con el culto al "tío" en las minas del altiplano boliviano. El diablo entró en la mentalidad andina en una suerte de "reversión irónica de la evangelización”, ya que pasó a formar parte de los ritos y prácticas sociales de reciprocidad. Pese al estigma cristiano del pecado, las poblaciones andinas mantuvieron oculta la noción de la dualidad que permitía equilibrar las fuerzas maléficas o benéficas que la figura del demonio contenía ya a su haber ${ }^{68}$.

El culto al diablo "supay" en las zonas de actividades mineras como Oruro o Potosí, fue asociado al "tío". Esta deidad reside al interior de las minas a la cual deben

\footnotetext{
${ }^{63}$ Bertonio 1612: 200.

${ }^{64}$ Bertonio 1612: 314.

${ }^{65}$ Bertonio 1612: 309.

${ }^{66}$ Gonçalez Holguin 1608:151.

${ }^{67}$ Gonçalez Holguin 1608: 122.

${ }^{68}$ Wachtel 2001:556.
} 
ch `allary ofrendar coca, alcohol, serpentinas y respetar sus dominios telúricos. Esta devoción se ha vinculado a la deidad precolonial Wari ${ }^{69}$, y su imagen representa al diablo desnudo con los ya clásicos atributos del macho cabrío. El "tio", si la "costumbre" es bien realizada, puede entregar al minero ricas vetas. No obstante, si no lo es, causa graves accidentes en el mundo de las profundidades de las minas ${ }^{70}$.

La tradición andina señala que a comienzos del mes de agosto se abre la superficie terrestre y se generan grietas en la tierra. Este es el momento en que se pueden hallar tesoros ocultos entre las grietas. En algunas comunidades los lugareños suben a los mallkus o cerros protectores para realizar ofrendas a los dioses tutelares con el fin de que les vaya bien en sus negocios, ya que durante este tiempo la pachamama "hambrea" pide ritos que la sacien para mantener el orden y la seducción religiosa ${ }^{71}$. En tal contexto ceremonial y simbólico, el mes de agosto paulatinamente se transforma en el "mes del diablo" para los comuneros ${ }^{72}$.

En el Departamento del Cusco (Perú) se encuentra la localidad de Paucartambo. En este lugar se celebra la fiesta de la Virgen de Carmen en la que participan comparsas de danzantes como las Qhapaq Ch'unchu. Este baile representa a las tribus selváticas ubicadas al oriente de los Andes, muy similares a las cofradías de "chunchos" que bailan en La Tirana. Además, participan las cofradías de los Qhapaq Qulla (que simbolizan a los comerciantes altiplánicos); Majeño (antiguos arrieros); Mestiza Qullacha (danza de la agricultura); Waka-Waka (recreación de una corrida de toros); Chukchu (representan a los peones que iban desde Paucartambo a la selva y contraían el paludismo); Siklla (danza de los doctorcitos); K'achampa (baile Inca de los jóvenes guerreros), etc. También danzan los Auq'a Chileno, quienes representan a los soldados chilenos que invadieron territorios peruanos durante la guerra del Pacífico. Participa un caporal acompañado de una dama y varios soldados. Son acompañados por violines, quenas, arpa y un bombo.

Durante la festividad de Paucartambo en honor a la "mamacha Carmen" como suelen llamarla, es posible ver danzar a los "saqra", que según sabemos corresponden al diablo, el cual tiene como principal atributo ser un personaje travieso. Desde la perspectiva de la teatralidad, los "saqra" mantienen un juego de poder con la Virgen, tentando a la feligresía con movimientos bruscos y giros vistosos. $\mathrm{Al}$ igual que en La Tirana los diablos no pueden entrar a la iglesia con máscaras.

La comparsa de diablos la integran Lucifer (caporal), una "china saqra" o Luzbel (mujer acompañante del caporal) y dos filas de demonios encabezadas por capitanes. También participan niños vestidos como diablos conocidos como

${ }^{69}$ Platt 1983.

${ }^{70}$ En los Andes las minas eran consideradas como wakas; se ofrendaba con coca tanto en la bocamina como en los interiores de esta. Las madres de las cosechas (mamas) poseían un poder genésico, es decir, generador del mineral. Esta idea de la renovación del mineral también se presenta en la cosmovisión española. Estos, al estar impregnados con creencias alquimistas "pensaban que la humedad del azufre y del mercurio junto con la influencia de los planetas y del Sol engendraba el mineral, y según una opinión popular algunas minas gozaban incluso de la propiedad de renovarse si se dejaban de explotar por algún tiempo". Cf. Bouysse-Cassagne 2005:447.

${ }^{71}$ Fernández 1997:116.

${ }^{72}$ Albó 2002:403. 
mascotas. Los “saqra” son acompañados por la música de violines, quenas, arpa, acordeón y un bombo ${ }^{73}$ (ver imagen $\mathrm{N}^{\text {os }} 8$ y 9 ).

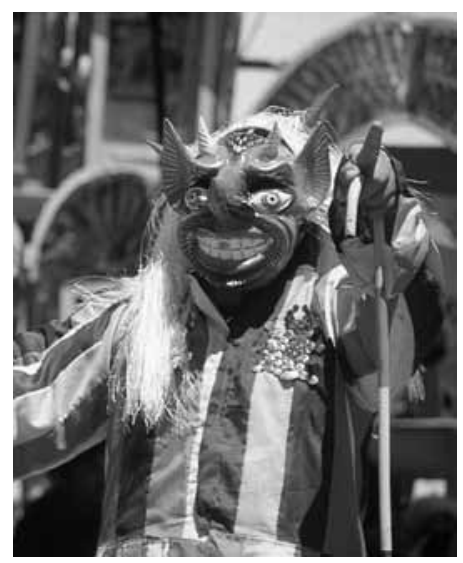

Imagen $\mathrm{N}^{\circ} 8$

El diablo "saqra" danzante en la fiesta de la Virgen del Carmen de Paucartambo (Perú) (Cánepa 1998).

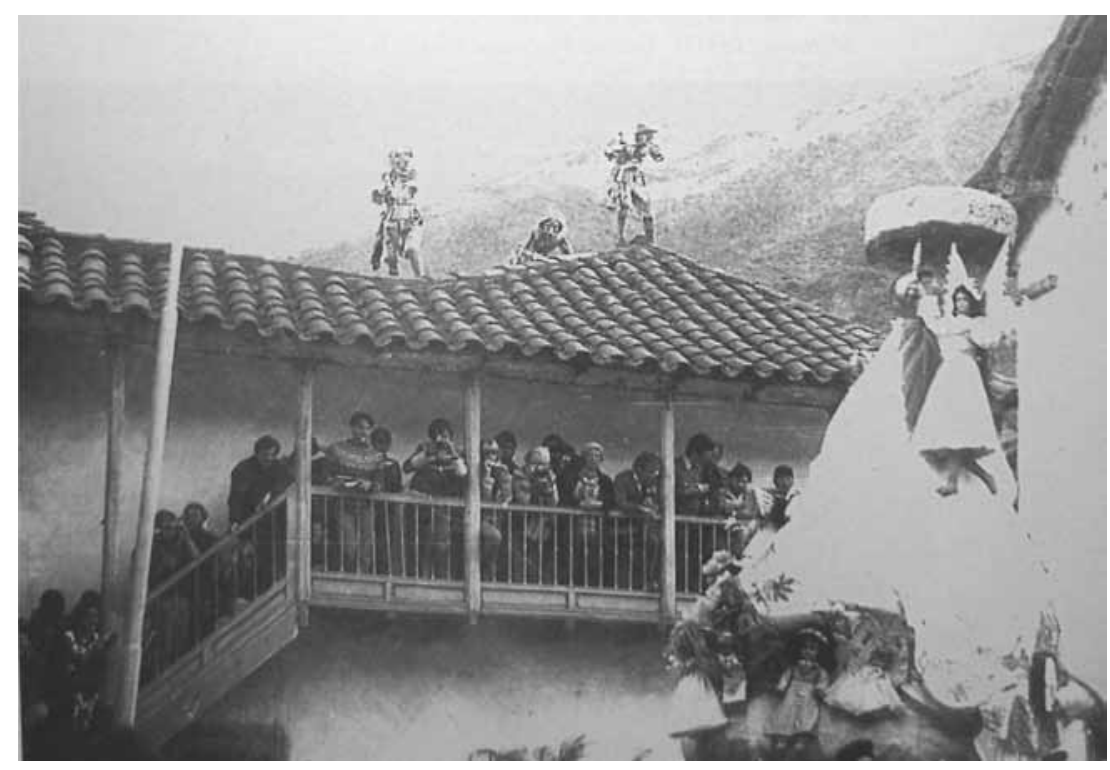

Imagen $\mathrm{N}^{\circ} 9$

Procesión de la Virgen del Carmen en Paucartambo,

Sobre los techos los demonios la acechan (Cánepa 1998). En la fiesta de San Lorenzo de Tarapacá algunos peregrinos también se suben a los techos a gritar y burlarse de la gente durante el amanecer del día 10 de agosto.

${ }^{73}$ Canepa Koch 1998:101-121. 


\section{LOS DEMONIOS DANZANTES EN LA TIRANA}

En la fiesta en honor a la Virgen del Carmen de La Tirana en el Norte Grande de Chile es posible distinguir dos tipos de bailarines que visten de diablos: los diablos sueltos y las agrupaciones de diabladas. Estos últimos corresponden a sociedades religiosas que danzan con enormes máscaras en mudanzas que representan la lucha entre las fuerzas de Dios y del Diablo. Poseen una clara influencia de las diabladas bolivianas de Oruro fundadas hacia fines del siglo XIX ${ }^{74}$, que bailan a la "Virgen del Socavón" durante el carnaval" ${ }^{75}$. Esta influencia se advierte tanto en sus vestimentas como en los personajes que asumen de los antiguos "autos sacramentales", con la salvedad de que el arcángel San Miguel que se enfrenta a los demonios ha sido reemplazado en La Tirana por la figura de un "angelito", traje que lo viste una niña pequeña que danza con una varita ${ }^{76}$. Otro detalle diferenciador con las diabladas bolivianas lo constituye el hecho de que la diablada de Oruro danza durante los carnavales, a ritmo de marchas ${ }^{77}$. En La Tirana, en cambio, las diabladas bailan el ritmo de salto y lo hacen sólo en el mes de julio, acompañándose con bandas de instrumentos de bronce ${ }^{78}$.

Las diabladas tiraneñas se organizaron como agrupaciones hacia mediados del siglo XX. Fue en esa época que el peluquero iquiqueño Gregorio Órdenes, padre del actual obispo de la Diócesis de Iquique, reunió a varios figurines que vestían de diablo para darle cuerpo y sentido asociativo a la "Primera Diablada de Chile" en 1957. La influencia boliviana se dio a partir de 1960, año en que visitó la zona la "Diablada de Oruro", la que dejó patente su sello entre los bailarines nortinos. La prensa de la época registró lo siguiente:

"Una caravana integrada por [un] conjunto de danzantes religiosos, comerciantes y peregrinos de Oruro viajará el miércoles 13 del presente mes a La Tirana con el objeto de participar en las fiestas que en homenaje a la Virgen del Carmen se desarrollarán el sábado 16 en la mencionada localidad, situada en el interior del departamento.

${ }^{74}$ Fortún 1961.

${ }^{75}$ Abercrombie 1992.

${ }^{76}$ Henríquez 1996.

${ }^{77} \mathrm{Al}$ respecto el sacerdote y sociólogo Juan Van Kessel señala que "la Diablada, de origen también un baile masculino, ha tenido otro recurso coreográfico que le permitió recibir a las candidatas femeninas: sus figurines, 'fuera de fila' han sido osos, monos, cóndores y las supayas, diablas femeninas y seductoras de la región andina. Las supayas (o chinas supay, chinitas o bolivianitas) son precisamente las que han conocido gran expansión numérica y marcan las innovaciones coreográficas (...) El ritmo musical de la diablada, es el mismo que el del baile Gitano: El paso es igual al paso 1 del Gitano, que se ejecuta alternativamente saltando y de paso. El paso saltado se ejecuta con saltos cuanto más altos, en que, al descender sobre el pie derecho, mantiene levantado el izquierdo con la rodilla doblada y viceversa. Los brazos, con codos hacia afuera y ligeramente doblados se levantan horizontalmente a la altura del hombro, mientras que en la mano se sujeta la punta de la capa del bailarin; de este modo se imita claramente el vuelo del diablo. El paso o movimiento de paso, bajan también los brazos hasta la altura del pecho; pero manteniendo las puntas de la capa en las manos, aparentando las alas medio recogidas. Las bailarinas, o bolivianas, se mueven con un solo paso regular, sin saltos, modo de un flaneo, frívolo y seductor, las manos puestas en la cintura y moviendo las caderas en forma coqueta, hasta exagerada" (Van Kessel 1981: 27-40).

${ }^{78}$ Un estudio en profundidad sobre los músicos de las bandas de bronce en Díaz Araya 2009. 
La información, aun cuando no ha sido dada a conocer oficialmente a la Intendencia de la Provincia de acuerdo a la reglamentación internacional que rige para tal efecto, fue anticipada ayer por correspondencia particular al delegado municipal en la Tirana señor Andrés Farías Gamelly.

La misma fuente informativa agregó que los comerciantes integrantes de esa caravana entregaran al público concurrente a las ya mencionadas fiestas, productos típicos de Bolivia"79.

Esta visita fue un punto de inflexión. Permitió que figurines dispersos se congregaran en el rito de la danza tiraneña, para fundar la diablada "Servidores de la Virgen del Carmen" o "Primera Diablada de Chile" ${ }^{80}$, conocida popularmente como la "Diablada del Goyo" en homenaje a su fundador. Esta agrupación generó el que otros conjuntos de diablos se constituyeran como diabladas en ciudades como Calama, Arica y Tocopilla, u oficinas salitreras como Alianza y María Elena ${ }^{81}$. Incluso de la "Primera Diablada..." se escindieron otras diabladas como los "Siervos de María” y los "Siervos de Jesús y María”.

A diferencia de estas agrupaciones, participan además en La Tirana los históricos danzantes de diablos sueltos, figurines que se integran a otros bailes. Son danzantes que poseen su génesis, tal como lo analizamos en las páginas anteriores, en las procesiones europeas insertas en las procesiones religiosas durante la época colonial. Estos demonios recorrían las romerías fastidiando a la gente, asustando a los niños e interpelando los dogmas católicos para las fiestas de los santuarios marianos o para el Corpus Christi. Son danzantes que en su principio formativo nunca han estado sujetos a las normativas de las cofradías religiosas, aunque su actuar está integrado en un formato de piedad popular.

La danza de los diablos sueltos corresponde precisamente a bailarines que no están asociados a ninguna cofradía o sociedad religiosa en La Tirana, como sucede en otros santuarios como Sipiza, Tarapacá y Timalchaca.

Suelen vestir con trajes de raso o gabardina rojos (algunos desgastados o descoloridos por el paso de los años), con pantalones bombachos, camisa, pechera, guantes, faldellín decorado con lentejuelas y espejos, botas o zapatillas. Llevan además una capa que posee adornos bordados con motivos religiosos o de la iconografía andina, junto a una pequeña máscara de yeso o papel maché que representa una figura demoníaca con rostro humano, con claros atributos estéticos del macho cabrío, tal como la imagen elaborada del diablo durante la Europa medieval $^{82}$. Al respecto las siguientes fotografías describen con mayor claridad lo expuesto (ver láminas $\mathrm{N}^{\circ} 10$ al $\mathrm{N}^{\circ} 20$ ).

${ }^{79}$ Periódico El Tarapacá, 3 de julio, 1960.

${ }^{80}$ Núñez 1989: 110-111.

${ }^{81}$ Las diabladas fundadas en este período fueron: la "Gran Diablada Calameña" (1961), "Sociedad de Bailes Religiosos Diablada de Alianza" (1962), "Sociedad de Bailes Religiosos Diablada de Victoria" (1965), "Cuerpo de Baile la Auténtica Diablada de Tocopilla" (1960), "Sociedad de Bailes Religiosos Diablada del Sol" (1968), "Sociedad de Bailes Religiosos Diablada Oro Blanco" (1968), "Sociedad de Bailes Religiosos Diablada de San José de Coya Sur” (1969), entre otras.

${ }^{82}$ Muchembled 2006. 


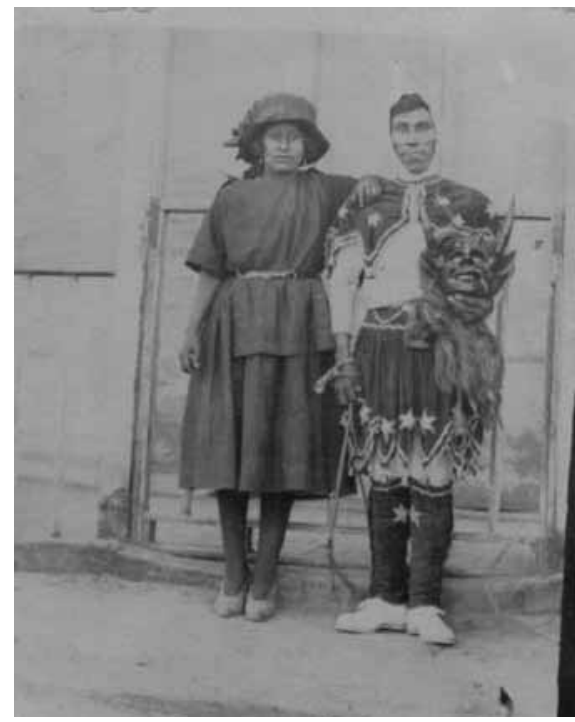

Imagen $\mathrm{N}^{\mathrm{o}} 10$

Diablo suelto de Tarapacá, década de 1920. Fotografía facilitada por Jorge Ocampo.

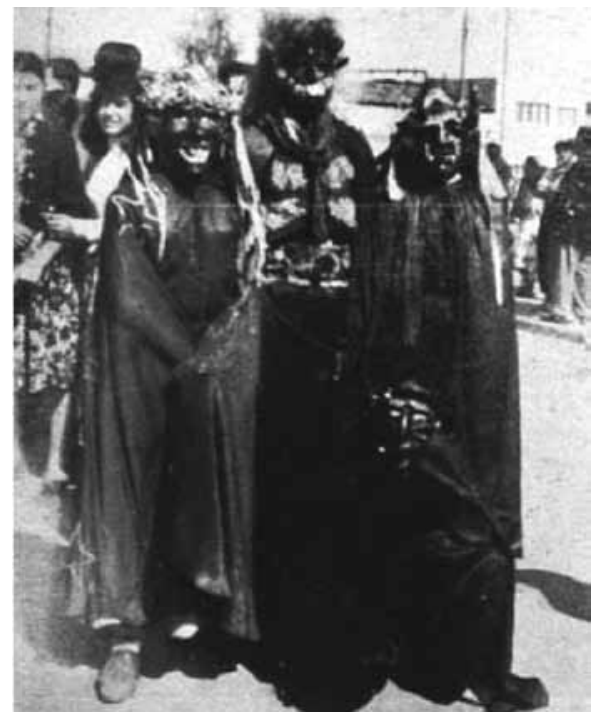

Imagen $\mathrm{N}^{\circ} 12$

Diablos sueltos en La Tirana 1953.

Fuente: Uribe Echeverría (1963).

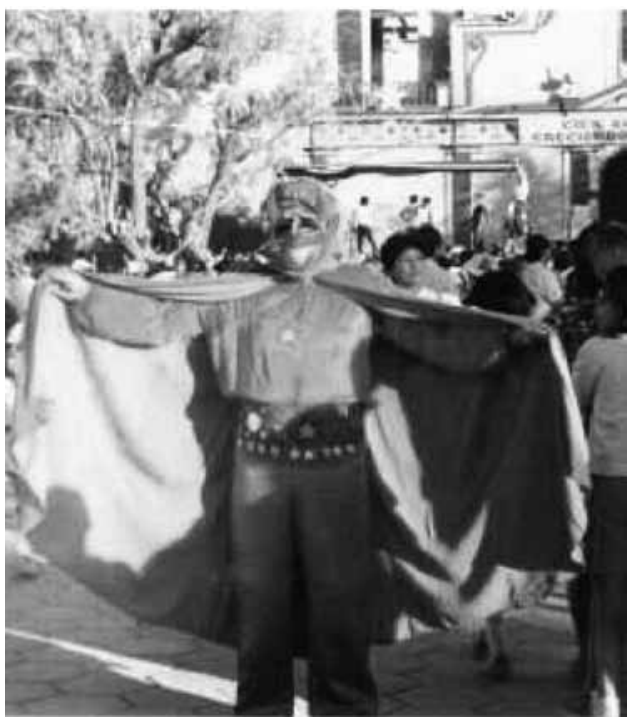

Imagen $\mathrm{N}^{\circ} 11$

Diablo suelto en La Tirana, década de 1970. Fotografía facilitada por Mario Vergara.

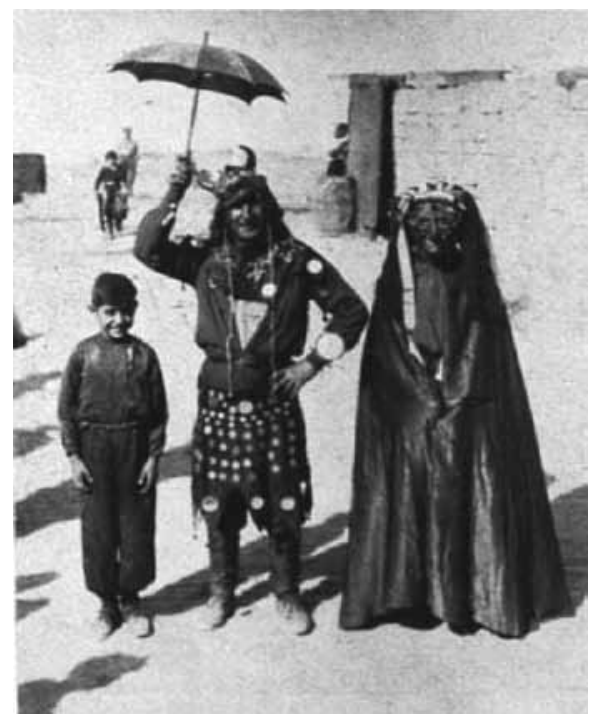

Imagen $\mathrm{N}^{\circ} 13$

Diablos descansando en La Tirana el año 1953. Fuente: Uribe Echeverría (1963). 


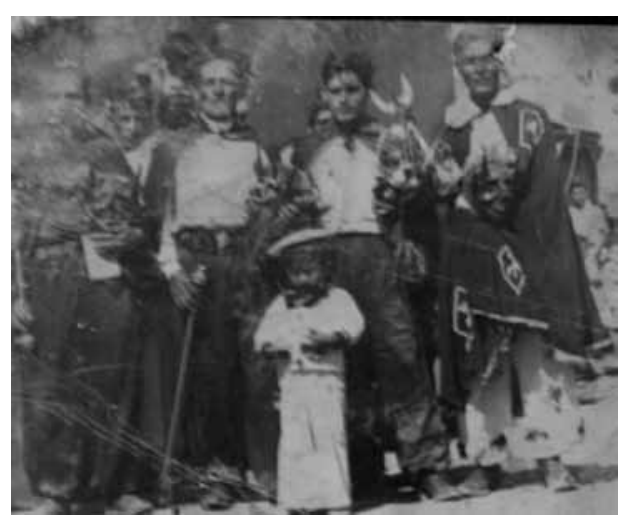

Imagen $\mathrm{N}^{\circ} 14$

Diablos sueltos de Tarapacá, década de 1920. Fotografía facilitada por Jorge Ocampo.

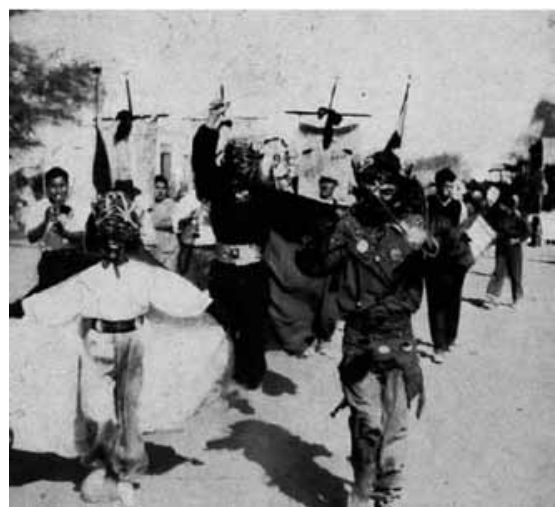

Imagen $\mathrm{N}^{\circ} 15$

Diablos sueltos en La Tirana 1953. Fuente: Uribe Echeverría (1963).

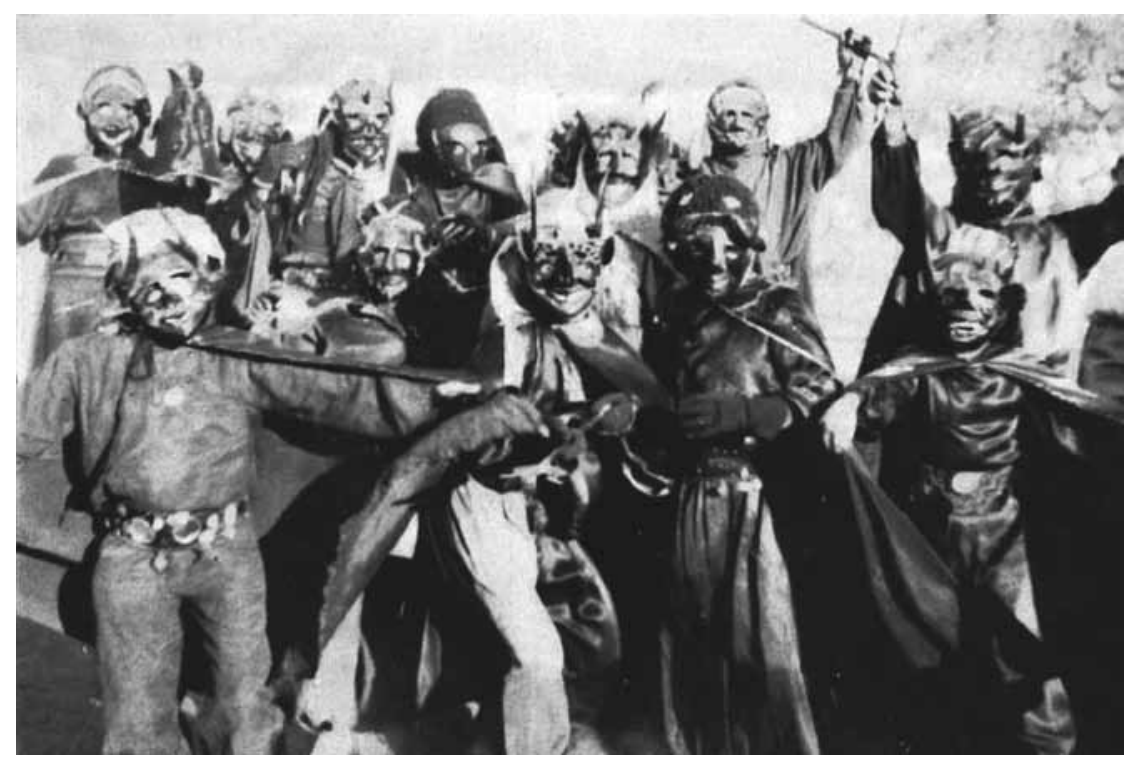

Imagen $\mathrm{N}^{\mathrm{o}} 16$

Diablos sueltos en La Tirana 1953.

Fuente: Uribe Echeverría (1963). 


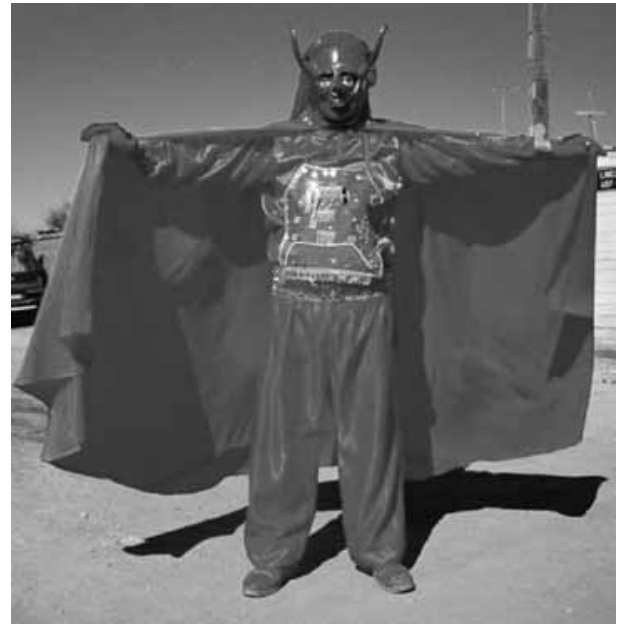

Imagen $\mathrm{N}^{\circ} 17$

Diablo suelto en La Tirana.

Fuente: Bascuñán 2008.

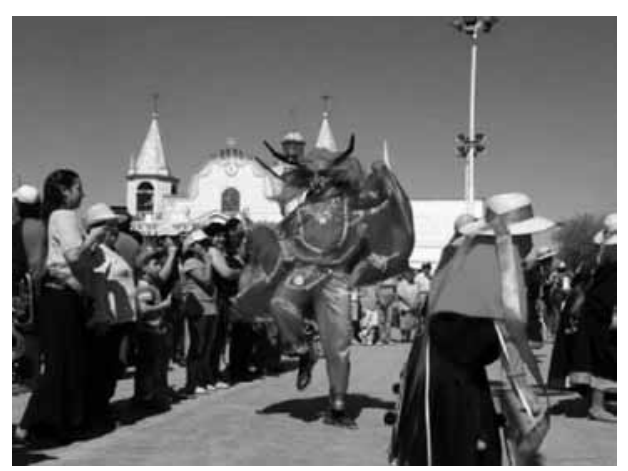

Imagen $\mathrm{N}^{\circ} 19$

Diablos sueltos danzando en el perímetro de un baile religioso en La Tirana (2008).

(Fotografía facilitada por Gabriel Alburquenque).

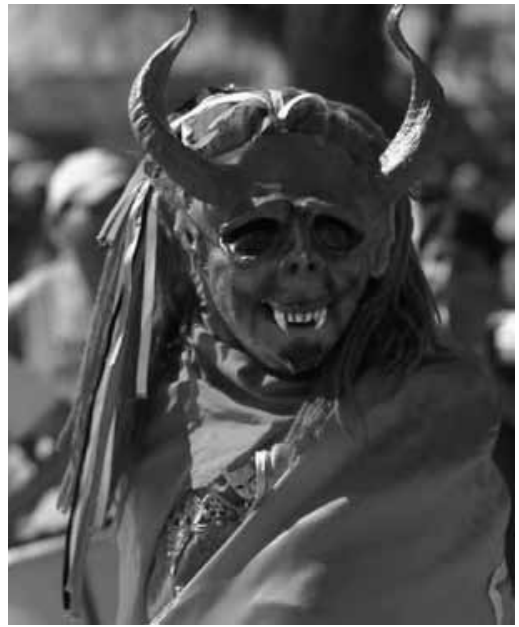

Imagen $\mathrm{N}^{\mathrm{o}} 18$

Detalle de máscara de diablos sueltos. (Fotografía facilitada por Gabriel Alburquenque).

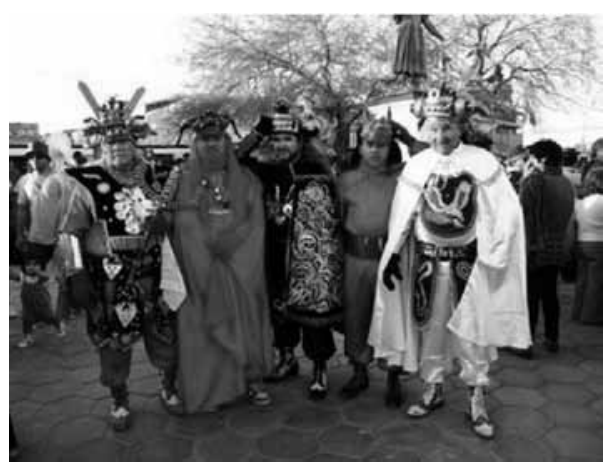

Imagen $\mathrm{N}^{\circ} 20$

Diablos sueltos en la plaza de La Tirana. (Fotografía de Juan Gálvez).

Esta singularidad de los diablos sueltos fue advertida por Juan Uribe Echeverría a mediados del siglo $\mathrm{XX}$. Al respecto, señala lo siguiente:

"los diablos o figurines son bailarines individuales que acompañan a cualquier compañía. De pronto se reúnen cuatro o cinco y bailan en conjunto. Son personas que han cometido un grave pecado o han recibido un favor extraordinario de la Virgen y para expiar culpas o agradecer perdones visten de diablo. El traje convencional es de paño rojo, cola del mismo color y máscara o antifaz con cuernos. Las máscaras bolivianas, muy usadas en La Tirana, son de variados colores y llevan serpientes o 
lagartijas enroscadas en los cuernos. Los diablos mayores usan peluca con trenzas o abundantes melenas" ${ }^{83}$.

Similares expresiones fueron expuestas por Carlos Lavín en la Revista Musical Chilena de 1950 al referirse a los diablos sueltos de La Tirana, quienes

“imponen su presencia por doquier las cuadrillas de 'diablos'. Alineados en dos filas, marchan adelante los tres de más reducida estatura y todos deben mimar el movimiento continuo. Sus vestes son rebuscadamente estrafalarias, con siluetas y actitudes que imitan el patrón mefistofélico. Una varita mágica o ramillete les sirve de complemento expresivo, en acción conjunta con los cuernos y prominencias de sus peculiares vestimentas. Su ubicuidad es realmente prodigiosa. En numerosos grupos, descomponen los dibujos de las danzas de otras falanges, intervienen en la procesión y figuran en los 'sketchs', integrando una participación similar a la de las 'girls' del teatro frívolo. Al margen de la disciplina rigurosa de las cohortes organizadas exacerban la euforia de todas las manifestaciones con el más sano y franco sentido de la alegría" ${ }^{84}$.

Tal como se detalla, existen diablos sueltos que visten ropajes a la usanza de las diabladas bolivianas, con enormes máscaras que asemejan una estampa cercana al dragón oriental, que incluyen extensos cachos, una nariz prominente y una serpiente de tres cabezas o dragón en la zona superior de la cabeza. A fines del siglo XIX artesanos orureños como Santiago Nicolás y sus hijos Hermógenes y Santiago Nicolás Vargas, aplicaron diseños que buscaron plasmar en las máscaras el estilo nativo de la deidad Wari. Estas caretas correspondían a rostros humanos con cuernos curvilíneos, una víbora sobre la cabeza, la nariz con una cierta dilatación en las fosas, arrugas en los pómulos, cejas destacadas y orejas de gran tamaño.

A partir de la década de 1930, Pánfilo Flores, discípulo de los hermanos Nicolás, implantó cambios significativos. Mantuvo ciertos rasgos, pero rescató la inclusión de pequeños lagartos que emulan movimientos en la nariz y la frente, una serpiente en la boca y un sapo atravesado por los dientes. Introdujo enormes colmillos y las cejas fueron delineadas; además aumentaron los tamaños de la nariz, los ojos y las orejas. Destaca a su vez, un dragón en la parte superior de la cabeza de la careta, la cual es mucho más grande a las anteriores que se asemejaban al rostro humano. En las máscaras de Flores hay una clara influencia de los estilos del dragón asiático, que se reflejan en los grandes ojos que rápidamente van a constituir la base del estilo orureño. Otros reconocidos artesanos que acrecentaron esta tendencia fueron Severino Flores, Mateo Moya, Eliseo Valencia, Walter Valencia, Freddy Aguilar y Mario Molina, entre otros. Ellos persistieron, pero en el estilo, introduciendo paulatinos cambios en las máscaras bolivianas ${ }^{85}$.

Las máscaras que utilizan los figurines en La Tirana son adquiridas principalmente en ferias o talleres artesanales en Oruro o La Paz (Bolivia) o mediante

\footnotetext{
${ }^{83}$ Uribe Echeverría 1963.

${ }^{84}$ Lavín 1950: 23.

${ }^{85}$ Vargas Luza 1998.
} 
intermediarios que las traen a Chile, ya sea como ventas vía comerciantes o por encargo a viajeros. En Iquique también existen un par de artesanos que confeccionan máscaras, tanto en los formatos orureños o en el estilo de los reconocidos diablos viejos.

El material para su manufactura corresponde a delgadas láminas de metal (o latón), pintadas en una variedad de colores (fosforescentes), además de adherir pequeños circuitos eléctricos para iluminar con luces o neón los ojos de la careta, cachos, nariz, verrugas, colmillos, orejas o la víbora tricéfala localizada junto a una corona cuando danzan en las noches de fiesta ${ }^{86}$. Años atrás, las máscaras se confeccionaban de yeso, lo que significaba un peso enorme que debían cargar los bailarines. En la actualidad, las caretas de latón son más livianas, lo que permite desarrollar diferentes piruetas sin cansar al danzante. Todos los diablos usan además pelucas que acompañan la vestimenta al estilo de Oruro (ver imágenes $\mathrm{N}^{\circ} 21$ a $\mathrm{N}^{\circ} 27$.

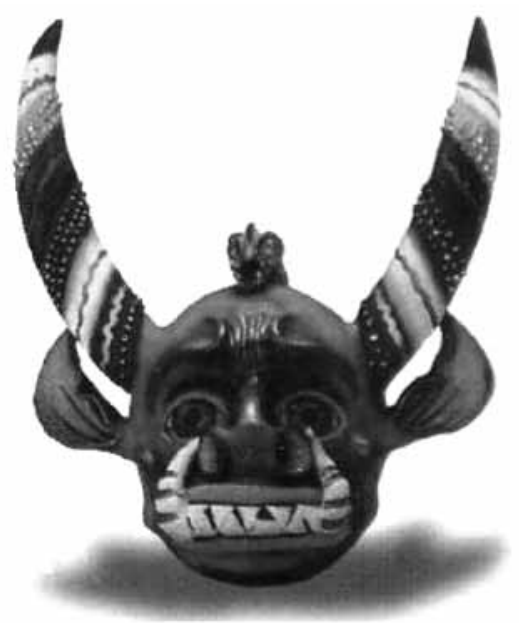

Imagen $\mathrm{N}^{\circ} 21$

Máscara de Oruro inicios del siglo XX. Fuente: Vargas (1998).

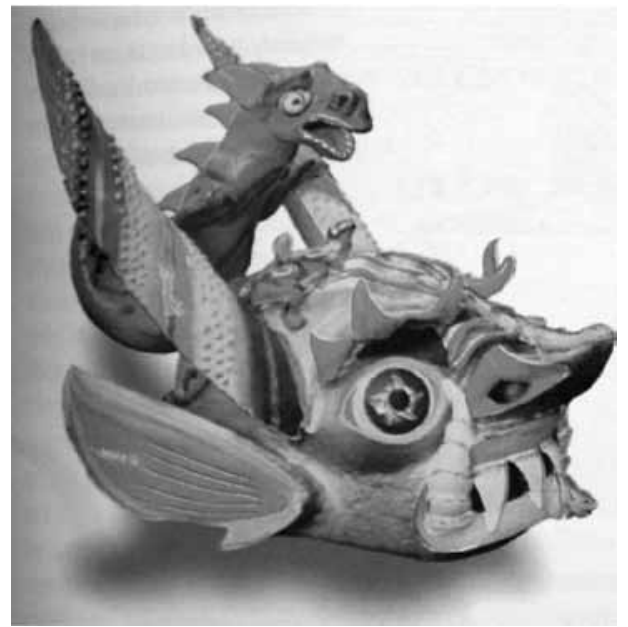

Imagen $\mathrm{N}^{\circ} 22$

Máscara de Oruro de 1940.

Fuente: Vargas (1998).

${ }^{86}$ Diabladas que han incorporado luces a las máscaras también se han registrado en Puno, Perú, zona en la cual son descritas como una danza "ritual gimnástica del sector aymara de los pueblos que circundan el lago Titicaca, ejecutan el compás de la alegre música de zampoñas. Los danzarines ostentan trajes de luces muy elegantes, se baila en ocasión de la festividad de la Octava de la Virgen de la Candelaria, Patrona de Puno y en las fiestas patronales de los pueblos aymaras. Los danzarines llevan una vestimenta lujosísima, recamada con hilos de oro y plata y cuajada de pedrerías deslumbrantes, completan rostros horribles cuajado de reptiles y con los ojos luceferinos que le dan un aspecto impresionante, unido al hermoso colorido. Los personajes son los caporales o diablos principales, con hermosas capas de terciopelo; los diablos con pañuelos de seda que les caen de los hombros, con una pechera bordada y un faldellín calado y ricamente bordado, que le posibilitan los saltos gimnásticos. La china diabla que es hembra de caporal, el viejecito semejante a un personaje virreinal; el Ángel que representa la salvación y la paz; el diablillo y otros que representan diversos animales, a manera de un rito de la creación; bailan al compás de los sicuris. Danza peculiar del Altiplano Peruano distinto de la de Bolivia; por su contenido terrígeno más puro" (Paniagua Loza 198: 28). 


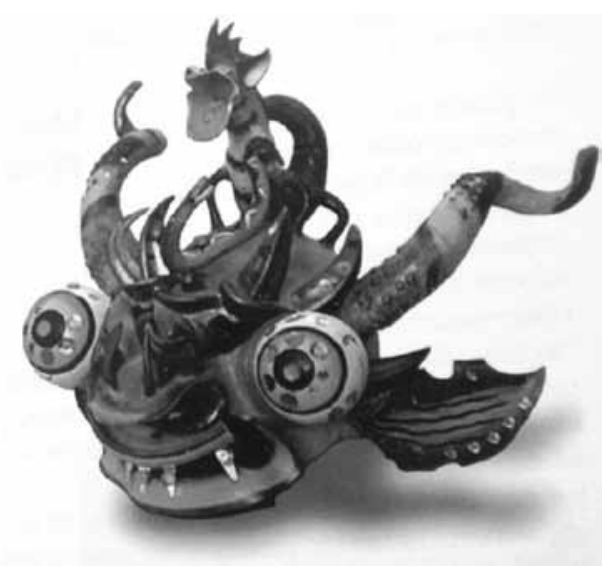

Imagen $\mathrm{N}^{\circ} 23$

Máscara de Oruro de mediados del siglo XX. Fuente: Vargas (1998).

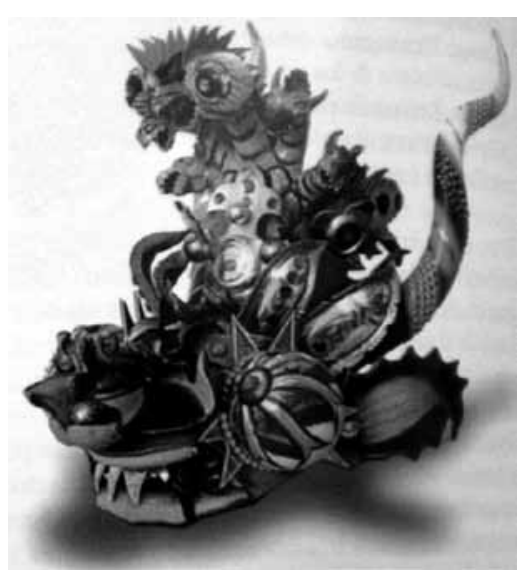

Imagen $\mathrm{N}^{\circ} 24$

Máscara de Oruro de 1968.

Fuente: Vargas (1998).

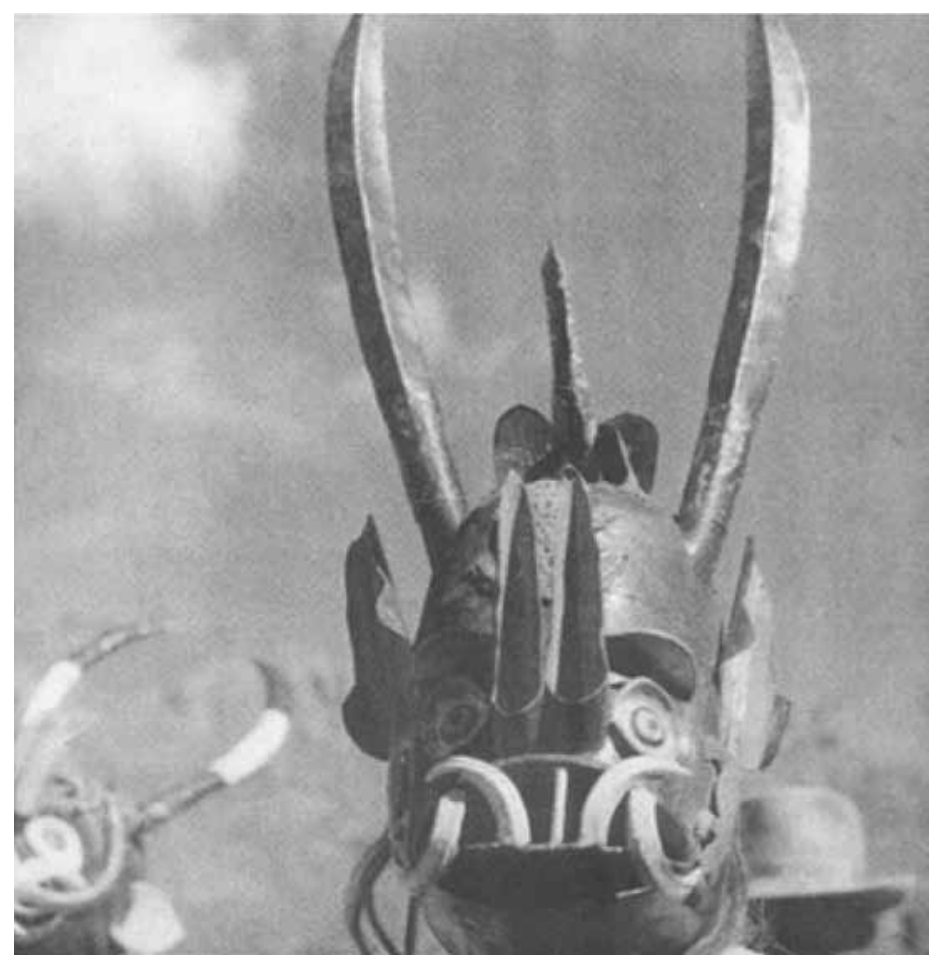

Imagen $\mathrm{N}^{\circ} 25$

Máscara de diablo de San Pedro de Ichu (Verger 1945) . 


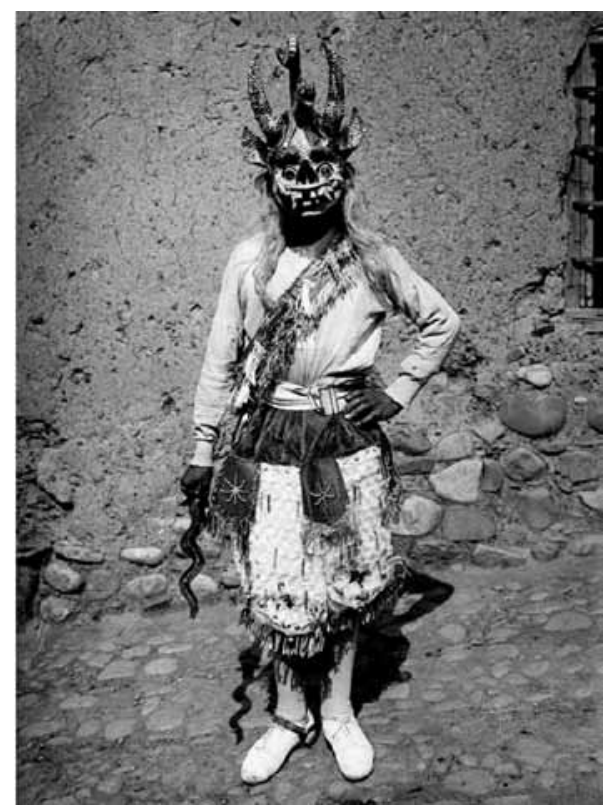

Imagen $\mathrm{N}^{\circ} 26$

Diablo Menor de la fiesta de Puno, según Martin Chambi (1925).

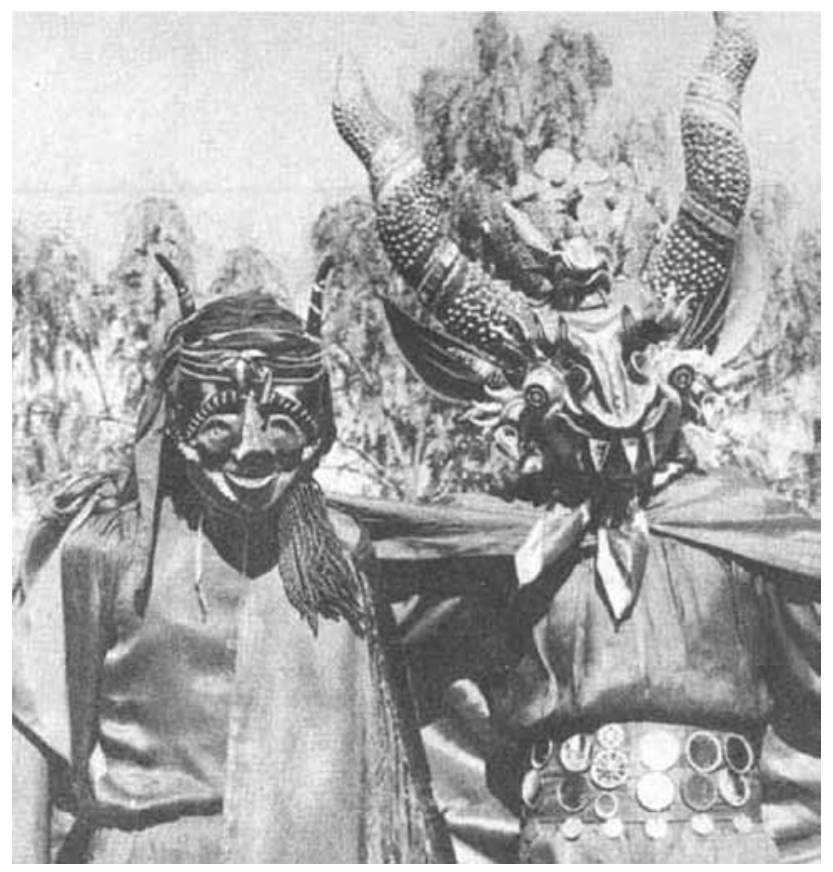

Imagen $\mathrm{N}^{\circ} 27$

Diablos sueltos de La Tirana con máscaras tradicionales y orureñas de mediados del siglo XX. Fuente: Plath 1961. 
Los diablos sueltos que siguen el patrón de vestir orureño, llevan coloridas botas blancas con decoraciones de cuero rojo o negro según el color del traje, los que son semejantes a fuegos o dragones. En algunos casos incluyen cascabeles; llevan puesto un "buzo" compuesto por pantalones bombachos y camisa de seda, satín, gabardina, raso o ponyé, muñequeras que cubren el antebrazo con iguales motivos y colores a la capa o al pollerín; pecheras con bordados religiosos, espejos y lentejuelas; faldellines (o pollerín de 5 puntas) bordados y con espejos, guantes, pañuelos y una lujosa capa con motivos de Cristo o María ${ }^{87}$. Últimamente han incluido imágenes de Viracocha, Tunupa o dragones como diseño en la parte central de la capa. En los extremos de estas llevan ganchos o tiras para sujetarla mientras extienden los brazos al brincar durante el baile. Aparte de la vestimenta de diablo, hay danzantes que se visten como osos negros, blancos o grises, con atuendos completos que asemejan a este mamífero, una máscara y guantes con pezuñas de $\operatorname{caprinos}^{88}$.

Antiguamente los trajes se confeccionaban en Iquique, con telas que asemejaban pieles y ponían en guantes oscuros los moldes cilíndricos que se utilizaban para preparar "dulces" llamados "cachitos", que se asemejaban a las pezuñas de los osos. Estas se golpeaban entre los dedos, generando el estruendoso sonido de las pezuñas de los animales. También hay trajes de achachis (abuelos), cóndor, indios tobas o chinas supay (diabla). No obstante, en definitiva a todos corresponde la clasificación de figurines reconocidos localmente como diablos sueltos. No son bufones ni saltimbanquis como lo fueron en el pasado. Al respecto se informaba a inicios del siglo XX que a La Tirana:

"acuden comparsas de danzantes indios que visten los trajes más extravagantes y ejecutan bailes o danzas en los que se notan muchos resabios de paganismo... Descuellan entre las numerosas comparsas, los morenos, cuyos bailes tienen numerosas figuras y son un tanto pintorescos. Las cuadrillas compuestas de doce a quince individuos son dirigidas por un caporal jefe de los danzantes y á la vez es quien hace el gasto, en cumplimiento de algún voto religioso. El caporal dirige el baile, ordenando todos los cambios de figuras con una chicharra y alrededor de los danzantes es de rigor que se hagan cabriolas y dé saltos y carreras vertiginosas un individuo que lleva el grotesco traje de diablo con su correspondiente máscara" 89 (cursiva agregada).

En la actualidad, son danzantes que individualmente se integran o acoplan a los distintos cuerpos de bailes durante la festividad del 16 de julio. Recorren el

${ }^{87}$ Henríquez 1996.

${ }^{88} \mathrm{El}$ uso de pezuñas o cachos de cabras para realizar trajes de bailarines ha sido registrado en el altiplano peruano en danzas como el Lancayu, la cual corresponde a "una danza que se ejecuta con música, producida por los cencerreos de los danzarines. Es una representación satírica del diablo que danza, a diferencia de la diablada boliviana; utilizando ropa auténtica, constituye la danza preparatoria de los momentos de aprestamiento a la batalla y que constituía una forma de acobardar al enemigo. La máscara de los danzarines lleva dos cuernos de carnero y es acompañada de los chasquidos de las reatas que manejan los lanlacus, moviéndose rítmicamente" (Barrientos Quispe 2006:89).

${ }^{89}$ Periódico El Tarapacá, 15 de julio, 1907. El subrayado es nuestro. 
perímetro del espacio que ocupa el grupo mientras desarrollan sus respectivas mudanzas o coreografías ${ }^{90}$.

Tal como se señalara, los diablos sueltos circulan alrededor de las cofradías, siguiendo el ritmo que acompañan a bailes como los chunchos, antawaras, gitanos, morenos, indios sioux, pieles rojas o dakotas. Todos poseen como base rítmica los "saltos", ritmo conocido popularmente como el "dos por tres", hasta que finaliza la cofradía el despliegue coreográfico. Posteriormente se dirigen a otras agrupaciones para replicar el modelo, y así sucesivamente, se movilizan por distintos grupos de bailes tanto en el día como en la noche.

En algunas agrupaciones deben solicitar permiso al caporal para realizar el circuito del perímetro y se encuentran en ocasiones con respuestas negativas. No obstante en la mayoría de los casos son aceptados. Incluso se insertan hasta cerca de 15 a 20 diablos sueltos, los que circulan acompasadamente alrededor del grupo, batiendo sus capas, mientras inclinan rítmicamente la cabeza hacia adelante y atrás, como un demonio con características animalescas. La gente al verlos transitar los fotografía o filman. Además les solicitan ser retratados junto a ellos cuando descansan, tomando como telón de fondo la fachada de la iglesia.

Siguiendo la ritualidad de los otros bailes, los diablos sueltos se integran a un grupo mientras este realiza el saludo en el calvario o en el templo al venerar la imagen de la "China”. En este caso no utilizan la máscara, también se integran a un grupo en la despedida durante el último día de la festividad, con la que participan de la estructura que posee el sistema ritual de la festividad. Algunos danzantes eligen saludar o despedirse privadamente de la Virgen, incluso sin el traje de diablo.

Un antecedente no menor lo constituye el hecho de que la vestimenta del demonio puede servir tanto a hombres como a mujeres. No constituye un privilegio exclusivo del género masculino el asumir como figurín en las comparsas. No existe restricción para la edad del bailarín, toda vez que se encuentran niños, adolescentes, adultos y abuelos que saltan bajo el ropaje del diablo. En otros términos, la condición etaria y de género no son requisitos determinantes para escenificar la fe mediante esta práctica cultural (ver imágenes $\mathrm{N}^{\circ} 28$ y No 29).

En otro plano existen agrupaciones que poseen figurines vestidos de osos, cóndor, achachis, indios tobas, quirquinchos, chinas supay o diablos, que pertenecen a dichas hermandades como un bailarín más. No obstante, en la mayoría de los casos, los diablos sueltos danzan solos. Pese a los diagnósticos catastróficos que los condenaban a desaparecer de las murgas tiraneñas, el número de diablos se ha incrementado significativamente en los últimos años a cerca de 100 bailarines o muchos más, con, incluso, sitios web.

\footnotetext{
${ }^{90} \mathrm{Al}$ respecto Van Kessel señala que las "mudanzas no tienen nada de improvisación personal. Las danzas de los diablos y de los animales no improvisan tampoco, aunque se ejecutan los 'solos'. Ya no existen danzas de improvisación sobre un tema, como por ejemplo en San Pedro de Atacama y en muchos pueblos andinos, pero estos bailarines no participan en las grandes fiestas de la región sino se limitan a festejar al patrón de su pueblo, San Pedro. Los bailarines de los grandes santuarios del Norte Grande, acostumbrados a las multitudes numerosas de espectadores y de turistas, no se muestran de ninguna manera impresionados. Jamás posan ante las cámaras". Van Kessel op. cit., 135.
} 


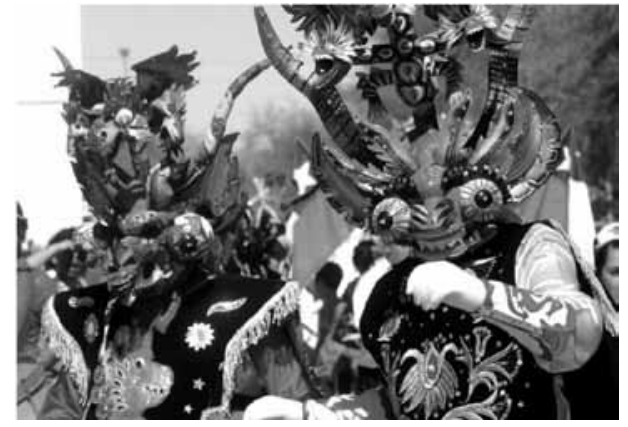

Imagen $\mathrm{N}^{\circ} 28$

Máscara utilizada en la actualidad por los Diablos sueltos (Fotografía facilitada por Gabriel Alburquenque).

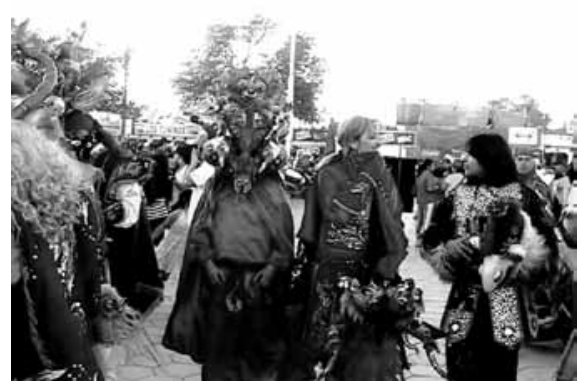

Imagen $\mathrm{N}^{\circ} 29$

Mujeres con traje de Diablo suelto y cóndor

(Fotografía facilitada por

Gabriel Alburquenque).

En este escenario han existido serios intentos por federarlos, ya que para algunos caporales la sola presencia de los diablos altera el orden de la coreografía o distrae a los bailarines y a los peregrinos. Se han realizado reuniones entre los diablos sueltos que provienen desde Arica, Calama, Alto Hospicio o Iquique, con el propósito de buscar la regimentación y organización en una sola comparsa, con distintivos propios, insignias y también estandartes, siguiendo las normativas vigentes de las federaciones de bailes religiosos que reconoce la Diócesis de Iquique. No obstante, dichos intentos han resultado infructuosos debido al principio de autonomía que rige como soporte social a estos demonios danzantes (ver imágenes $\mathrm{N}^{\circ} 30$ a $\mathrm{N}^{\circ} 32$ ).

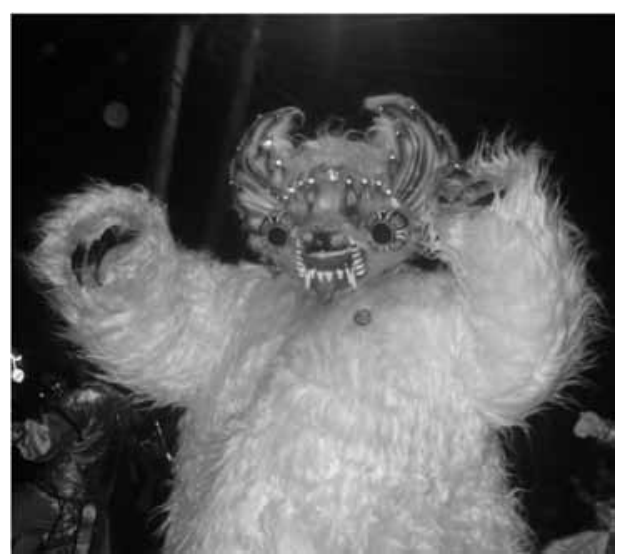

Imagen $\mathrm{N}^{\circ} 30$

Oso blanco danzando en La Tirana.

(Fotografía facilitada por Gabriel Alburquenque).

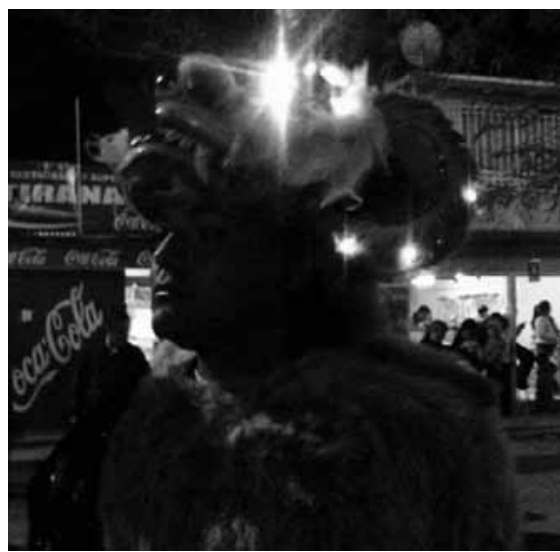

Imagen $\mathrm{N}^{\circ} 31$

Ricardo González Cruz ("el indio") con su máscara de oso gris iluminada. (Foto Familia González - Cruz). 


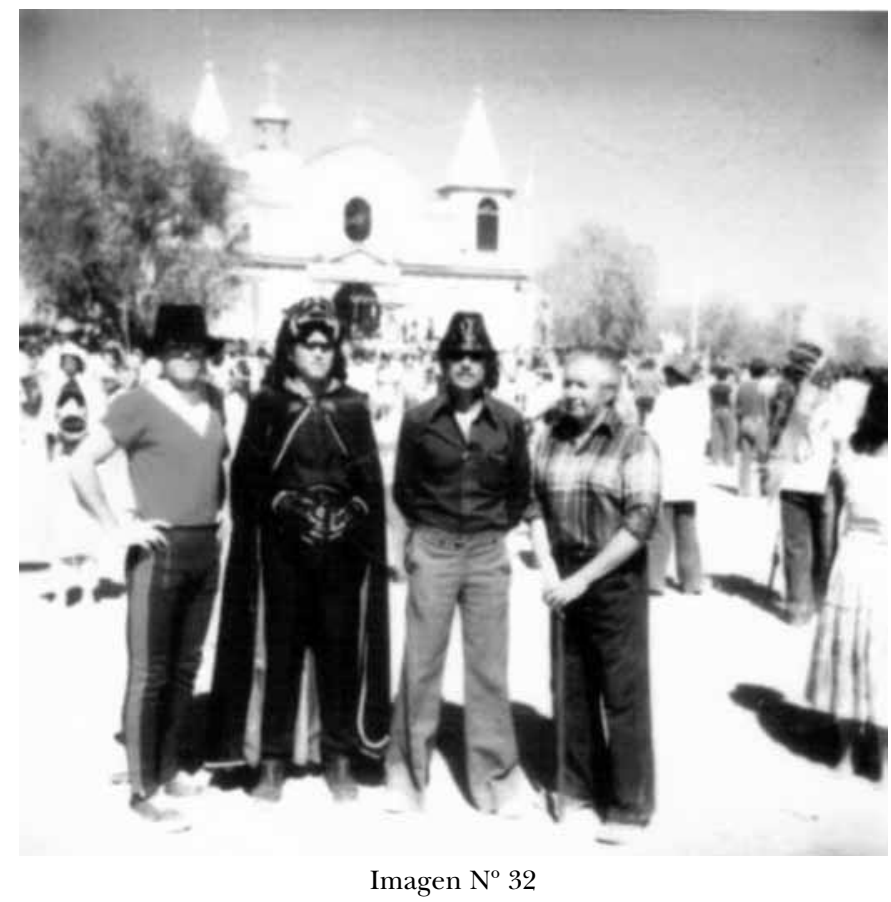

René Díaz, Jimmy Díaz, vestido de oso negro, Florentino Arancibia y Eugenio Araya Zamora, década de 1980. (Fotografía familia Díaz Salinas)

\section{COMENTARIOS}

A comienzos del siglo XX, una noticia en los periódicos nortinos sobre la festividad de La Tirana invitaba a los periodistas de la época a reflexionar sobre los danzantes que acudían al Santuario. Para ello esgrimía afirmaciones como:

"La imagen de la Virgen del Carmen sigue siendo objeto de veneración popular y allí concurren todos los años de dos a tres mil personas, entre devotos y devotos costumbre heredada en las que se han mezclado las prácticas religiosas del catolicismo con el antiguo ritual de los Incas" ${ }^{91}$.

Guardando la distancia de tiempo y contexto, es válido el argumento que identifica en las danzas tiraneñas una diversidad de elementos religiosos tanto católicos como nativos. De acuerdo con los antecedentes expuestos, es plausible la hipótesis que subraya que la devoción a la Virgen posee sus orígenes en la religiosidad generada en torno a las minas de plata de Huantajaya y Santa Rosa, yacimientos localizados en las serranías costeras cercanas al puerto iquiqueño, los cuales durante la época colonial poseían vetas y socavones consagrados a "Nuestra Señora del Carmen" y "Sacramento" 92 .

\footnotetext{
${ }^{91}$ Periódico El Tarapacá, 15 de julio, 1907.

${ }^{92}$ Hidalgo 2009.
} 
Dicho culto a la Virgen del Carmen fue celebrado a inicios de agosto hasta el siglo XIX (González 2006). Se trataba de tiempo mítico en el cual la tierra se “abre”, inaugurándose un ciclo en que el diablo recorre los diferentes parajes del mundo andino.

En localidades tarapaqueñas como Isluga y/o Chiapa, cuatro comuneros se vestían hasta hace pocos años como diablos. Realizaban travesuras en una serie de ceremonias para Semana Santa o para la fiesta de la "Asunta" (asunción de la Virgen), el 15 de agosto. Así, la danza de los diablos recorría ya diversos poblados como parte de una tradición de larga data que conjugó prácticas rituales autóctonas con el culto popular católico ${ }^{93}$.

Al tenor de los argumentos esgrimidos por Núñez, el traslado de la fiesta al 16 de julio reorientó, en principio, las prácticas devocionales, amén de viejas danzas que representaban las fuerzas del mundo animal salvaje que era domesticado y consagrado por la Virgen, como acontece en el correlato de La Tirana que constituye Paucartambo.

Del mismo modo, es llano conjeturar que diferentes elementos simbólicos, como bailes, máscaras y trajes existentes en otros sitios de los Andes tienen resonancia en cuanto a una manifestación musical y cultural en La Tirana. Tal es el caso de las danzas de chunchos y osos. Asimismo se advierten en el despliegue coreográfico de los diablos que, por un lado pueden lucir en cofradías organizadas que representan escenas bíblicas o teatralizaciones de obras medievales y coloniales. Por la otra vertiente, están los diablos sueltos, que buscan generar desorden ante el circuito de la procesión en homenaje a la Virgen, tal como sucedía en Corpus Christi. No por nada este último rito es celebrado en los meses previos a julio. Los diablos sueltos, muy distintos a las diabladas de influencia orureña, poseen un corpus de profundidad histórica que se hunde en el pasado regional andino, mucho más allá de la influencia del ciclo salitrero en La Tirana en los albores del siglo XX.

Cada año los danzantes con sus máscaras representan una alteración al orden social impuesto, generan una respuesta oculta tras el traje del demonio. Siempre están distanciados de las estructuras hegemónicas que sólo buscan regimentar el salto histórico de los diablos sueltos en la pampa.

\section{BIBLIOGRAFÍA}

\section{Periódicos}

El Copiapino, 26 de febrero de 1868.

El Tarapacá, 15 de julio, 1907; 3 de julio, 1960.

\footnotetext{
${ }^{93}$ Martínez 1979 [2009].
} 


\section{Libros y artículos}

Abercrombie, Tomás

1992 "La fiesta del carnaval postcolonial en Oruro: Clase, etnicidad y nacionalismo en la danza folklórica”, Revista Andina, $\mathrm{N}^{\circ}$ 20. Cusco, Perú: Centro Bartolomé de Las Casas (CBC).

Albó, Xavier

2002 "Preguntas para los historiadores desde los ritos andinos actuales", en Jean-Jaques Decoster (editor). Incas e indios cristianos. Elites indígenas e identidades cristianas en los Andes coloniales. Cusco, Perú: Centro de Estudios Regionales Andinos Bartolomé de Las Casas, IFEA, Asociación Kuraka, pp. 395-438.

Álvarez, BARTOLOMÉ

1588 [1998] De las costumbres y conversión de los indios del Perú. Memorial a Felipe II. Madrid: Ediciones Polifemo.

Arriaga, Pablo José de

1621 [1968] Extirpación de la idolatría del Perú [Biblioteca de Autores Españoles]. Madrid: Atlas.

Bajtin, Mijael

2003 La cultura popular en la Edad Media y en el Renacimiento. Madrid: Alianza Editorial.

Barrientos QUispe, WiLfRedo

2006 Etnografía de la Provincia del Collao. Publicación realizada por el Equipo de Investigación e Innovación Docente de Ciencias Sociales de la UGEL ${ }^{94}$. Ilave-Puno-Perú.

Bascuñán, Francisco

2008 Chile: imágenes a lo humano y a lo divino. Santiago: Ed. Ideograma.

BERTONIO, LUDOVICO

1612 [1984] Vocabulario de la lengua Aymara, Juli, Provincia de Chucuito, Perú. Cochabamba, Bolivia: Centro de Estudios de la Realidad Económica y Social CERES, Instituto Francés de Estudios Andinos IFEA, Museo Nacional de Etnografía y Folklore MUSEF.

Biblioteca Nacional del Perú (BNP), Libros raros y manuscritos

1973 Intendencia de Arequipa sobre la prisión de Dn. Francisco de Zela, fundidor, ensayador y balanzario de las reales cajas de Arica, practicadas por el Alcalde ordinario de Tacna. Tacna, mayo de 1793, fojas 2-3.

Bouysse-Cassagne, Thérese

2005 "Las minas del centro-sur andino, los cultos prehispánicos y los cultos cristianos", Bulletin de L'Institut Francais d'Etudes andines, XXXIV/3. Lima, pp. 443-462.

BRISSET, DEMETRIO

2002 "Diabladas andinas y granadinas", en Fermín del Pino (coordinador). Demonio, Religión y Sociedad entre España y América. Madrid: Consejo Superior de Investigaciones Científicas CSIC, pp. 301-322.

${ }^{94}$ El término UGEL corresponde a la expresión administrativa en Perú para referirse a las municipalidades. 
Busto, José

2002 "El demonio cristiano: invariantes", en ibid., pp. 23-32.

Calvo Pérez, Julio

2001 "Uska Pawkar 'El rico más pobre': Un 'auto sacramental' en lengua quechua", en Julio Calvo (editor). Contacto interlingüistico e intercultural en el mundo hispano. Volumen 2. Valencia, España: Instituto Valenciano de Lengua y Cultura Amerindias, pp. 583-605.

Callejo, Jesús

1999 Fiestas sagradas. Sus orígenes, ritos y significado que perviven en la tradición de los pueblos. Madrid: Editorial EDAF.

Campmany, Aurelio

1946 Folklore y costumbres de España. Barcelona: Ediciones Alberto Martín.

Canepa Koch, Gisela

1998 Mascara. Transformación e identidad en los Andes. Lima: Pontificia Universidad Católica del Perú, Fondo Editorial.

Chacama Rodríguez, Juan

2009 "Imágenes y palabras, dos textos para un discurso: La prédica pastoral en los Andes coloniales. Doctrina de Codpa (Altos de Arica), siglo XVIII", Revista Diálogo Andino, No 33. Arica: Universidad de Tarapacá, pp. 7-27.

Cieza de León, Pedro

1553 [1880] Primera parte de la crónica del Perú. Montesdoca, Sevilla: Marcos Jiménez de la Espada [Biblioteca Hispano-Ultramarina]. Madrid: Imprenta Manuel Ginés Hernández.

De Certeau, Michel

2004 La fábula mistica. Siglos XVI-XVII. México: Universidad Iberoamericana.

De Murúa, Martín

1590 [1946] Historia del origen y genealogía real. Reyes Incas del Perú. Madrid: Consejo Superior de Investigaciones Científicas CSIC.

De Torres Rubio, Diego

1619 Arte de la lengua Quichua. Lima: Compañía de Jesús.

Díaz Araya, Alberto

2009 "Los Andes de Bronce. Conscripción militar de comuneros andinos y el surgimiento de las bandas de bronce en el norte de Chile (1900-1950", Revista Historia, II/42 (julio-diciembre). Santiago: Pontificia Universidad Católica de Chile, pp. 371-399.

Duviols, Pierre

1997 La destrucción de las religiones andinas. (Conquista y Colonia). México: Universidad Nacional Autónoma de México.

ENRICH, Francisco

1891 Historia de la Compañia de Chile. Barcelona: Francisco Rosal, Barcelona.

FERnÁndez, GERARdo

1997 Entre la repugnancia y la seducción. Ofrendas complejas en los Andes del Sur. Cusco, Perú: Centro de Estudios Regionales Andinos Bartolomé de Las Casas. 
Fortún, JULia

1961 La danza de los diablos. La Paz, Bolivia: Imprenta El Progreso.

García Arribas, José

1989 Los bailes religiosos del norte de Chile o los Danzantes de la Virgen. Santiago: Seminario Pontificio Mayor de los Santos Ángeles Custodios.

Garcilaso de la Vega, Inca

1984 Comentarios reales. México: Editorial Porrúa.

GEIST, INGRID

1996 "Teatralidad y ritualidad: el ojo del etnógrafo", en Ingrid Geist (compiladora). Procesos de escenificación y contextos rituales. México: Universidad Iberoamericana, pp. 163-178.

Gisbert, Teresa

1999 El paraíso de los pájaros parlantes. La imagen del otro en la cultura andina. La Paz, Bolivia: Plural Editores, Universidad Nuestra Señora de La Paz.

Godoy, Milton

2007 “¿Cuándo el siglo se sacará la máscara! Fiesta, carnaval y disciplinamiento cultural en el Norte Chico. Copiapó, 1840-1900”, Revista Historia, I/ 40 (enero-junio). Santiago: Pontificia Universidad Católica de Chile, pp. 5-34.

Gonçalez Holguín, Diego

1608 [1952] Vocabulario de la lengua general de todo el Perú llamada lengua Quichua o del Inca. Lima: Edición del Instituto de Historia/ Imprenta Santa María.

GonZÁlez, Sergio

2006 "La presencia indígena en el enclave salitrero de Tarapacá: Una reflexión en torno al fiesta de La Tirana", Chungara, Revista de Antropología Chilena, XXXVIII/1. Arica, pp. 35-49.

Guamán Poma de Ayala, Felipe

1615 [1992] El primer nueva coronica y buen gobierno. Edición a cargo de John V. Murra, Rolena Adorno y Jorge Urioste. México: Siglo XXI Editores.

Henríluez Rojas, Patricia

1996 Por qué bailando: estudio de los bailes religiosos del Norte Grande de Chile. Santiago: Printext.

Hidalgo, Jorge

2009 "Corregidores ilustrados en el desierto de Arica, Tarapacá y Atacama 1760-1780", Boletín de la Academia Chilena de la Historia, $\mathrm{N}^{\circ}$ 118. Santiago, pp. 91-156.

LAAN, ERIC

1993 Bailar para sanar: estudio de la praxis de la peregrinación de los bailes religiosos del Norte de Chile. Iquique: Centro de Investigación de la Realidad del Norte.

Lavín, Carlos

1950 "La Tirana. Fiesta ritual de la Provincia de Tarapacá”, RMCh, VI/37 (otoño), pp. 12-36.

LEFEBVRE, GASPAR

1940 Misal diario y vesperal. Brujas, Bélgica: Desclée de Brouwer y Cia. 


\section{Macherel, Claude}

1999 "Corpus Christi, cosmos y sociedad", en Antoinette Molinié (editora). Celebrando el Cuerpo de Dios. Lima: Pontificia Universidad Católica del Perú, pp. 47-64.

MaLdonAdo, Luis

1985 Introducción a la religiosidad popular. Santander, España: Editorial Sal Terrae.

Martínez, Gabriel

1979 [2009] "Humor y sacralidad en el mundo autóctono andino", Chungara, Revista de Antropología Chilena, XLI/2. Arica, pp. 275-286.

Martínez Compañón y Bujanda, Baltasar Jaime

1776 [1987-1991] Trujillo del Perú. Tomo II [ Ediciones de Cultura Hispánica]. España: Agencia Española de Cooperación Internacional.

Muchembled, RoberT

2006 Historia del Diablo. Siglos XII-XX. México: Fondo de Cultura Económica.

NATividad, Fray JuAN de LA

1697 Coronada Historia... imagen de la Virgen de Gracia en convento Trinitarios. Granada, España.

Núñez Atencio, Lautaro

1989 La Tirana del Tamarugal. Del Misterio al Sacramento. Antofagasta: Universidad Católica del Norte.

Paniagua loza, Félix

1981 "Glosas de danzas del Altiplano Peruano", separata del Boletín de Lima, N $^{\circ} 15$. Lima, pp. 28-39.

Plath, Oreste

1961 En viaje. Santiago: Empresa de Ferrocarriles del Estado. Versión digital.

Platt, Tristán

1983 "Religión andina y conciencia proletaria. Qhuyaruna y ayllu en el norte de Potosî", HISLA Revista Latinoamericana de la Historia Económica y Social, No 2. Lima, pp. 47-74.

RICARD, ROBERT

2004 La conquista espiritual de México. Ensayo sobre el apostolado y los métodos misioneros de las órdenes mendicantes en la Nueva España de 1523-1524 a 1572. México: Fondo de Cultura Económica.

Romero, Pedro

1999 "Corpus Christi y Tauromaquia. Una fiesta bajo el signo de la muerte sacrificial", en Antoinette Molinié (editora). Celebrando el Cuerpo de Dios. Lima: Pontificia Universidad Católica del Perú, pp. 87-128.

Sans, María Jesús

2007 "La procesión del Corpus en Sevilla. Influencias sociales y políticas en la evolución del cortejo", Revista Ars Longa, № 16. Sevilla, España, pp. 55-72.

SCOTT, JAMES

2000 Los dominados y el arte de la resistencia. Discursos ocultos. México: Ediciones Era.

Trujillo, Valentín

1981 La legislación eclesiástica en el Virreynato del Perú durante el siglo XVI. Lima: Ed. Lumen. 
TURNER, Victor

1974 Dramas, Fields and Metaphors. Symbolic Action in Human Society. Ithaca y Londres: Cornell University Press.

TURNer, Victor

1988 The Anthropology of Performance. Nueva York: PAJ Publications.

URIBE ECHEVERRía, JUAN

1963 “La Tirana de Tarapacá”, Revista Mapocho, № 2. Santiago, pp. 83-122.

VAlenzuela, Jaime

2001 Las liturgias del Poder. Celebraciones públicas y estrategias persuasivas en Chile colonial (1609-1709). Santiago: Centro de Investigaciones Diego Barros Arana, Dibam, LOM Ediciones.

VAN KeSSEL, JUAN

1981 Danzas y estructuras sociales de los Andes. Cusco: Ediciones IPA.

VAN KeSSEL, JuAN

1988 Lucero del desierto. Iquique: Centro de Investigación de la Realidad del Norte.

VARgas LuZa, Jorge

1998 La Diablada de Oruro. Sus máscaras y caretas. La Paz, Bolivia: Plural Editores.

Verger, Pierre

1945 Fiestas y danzas en el Cuzco y en los Andes. Buenos Aires, Argentina: Editorial Sudamericana.

WACHTEL, NATHAN

2001 El regreso de los antepasados. Los indios Urus de Bolivia, del siglo XX al XVI. Ensayo de historia regresiva. México: El Colegio de México, Fondo de Cultura Económica.

Wilde, Guillermo y Pablo Schamber

2006 Simbolismo, ritual y performance. Buenos Aires: Editorial SB. 